\title{
Agricultural ammonia emissions in China: reconciling bottom-up and top-down estimates
}

\author{
Lin Zhang ${ }^{1}$, Youfan Chen ${ }^{1}$, Yuanhong Zhao ${ }^{1}$, Daven K. Henze ${ }^{2}$, Liye Zhu ${ }^{3}$, Yu Song ${ }^{4}$, Fabien Paulot ${ }^{5}$, Xuejun Liu ${ }^{6}$, \\ Yuepeng Pan $^{7}, \mathrm{Yi} \mathrm{Lin}^{8}$, and Binxiang Huang ${ }^{9}$ \\ ${ }^{1}$ Laboratory for Climate and Ocean-Atmosphere Studies, Department of Atmospheric and Oceanic Sciences, \\ School of Physics, Peking University, Beijing 100871, China \\ ${ }^{2}$ Department of Mechanical Engineering, University of Colorado, Boulder, CO 80309, USA \\ ${ }^{3}$ Department of Atmospheric and Oceanic Sciences, University of California, Los Angeles, CA 90095, USA \\ ${ }^{4}$ State Key Joint Laboratory of Environmental Simulation and Pollution Control, Department of Environmental Science, \\ Peking University, Beijing 100871, China \\ ${ }^{5}$ Program in Atmospheric and Oceanic Sciences, Princeton University, Princeton, NJ 08544, USA \\ ${ }^{6}$ Key Laboratory of Plant-Soil Interactions of MOE, College of Resources and Environmental Sciences, \\ China Agricultural University, Beijing 100094, China \\ ${ }^{7}$ State Key Laboratory of Atmospheric Boundary Layer Physics and Atmospheric Chemistry (LAPC), \\ Institute of Atmospheric Physics, Chinese Academy of Sciences, Beijing 100029, China \\ ${ }^{8}$ School of Earth and Space Sciences, Peking University, Beijing 100871, China \\ ${ }^{9}$ Department of Agrometeorology, College of Resources and Environmental Sciences, China Agricultural University, \\ Beijing 100193, China
}

Correspondence: Lin Zhang (zhanglg@pku.edu.cn)

Received: 10 August 2017 - Discussion started: 17 August 2017

Revised: 25 November 2017 - Accepted: 1 December 2017 - Published: 12 January 2018

\begin{abstract}
Current estimates of agricultural ammonia $\left(\mathrm{NH}_{3}\right)$ emissions in China differ by more than a factor of 2, hindering our understanding of their environmental consequences. Here we apply both bottom-up statistical and top-down inversion methods to quantify $\mathrm{NH}_{3}$ emissions from agriculture in China for the year 2008. We first assimilate satellite observations of $\mathrm{NH}_{3}$ column concentration from the Tropospheric Emission Spectrometer (TES) using the GEOS-Chem adjoint model to optimize Chinese anthropogenic $\mathrm{NH}_{3}$ emissions at the $1 / 2^{\circ} \times 2 / 3^{\circ}$ horizontal resolution for MarchOctober 2008. Optimized emissions show a strong summer peak, with emissions about $50 \%$ higher in summer than spring and fall, which is underestimated in current bottom-up $\mathrm{NH}_{3}$ emission estimates. To reconcile the latter with the topdown results, we revisit the processes of agricultural $\mathrm{NH}_{3}$ emissions and develop an improved bottom-up inventory of Chinese $\mathrm{NH}_{3}$ emissions from fertilizer application and livestock waste at the $1 / 2^{\circ} \times 2 / 3^{\circ}$ resolution. Our bottom-up emission inventory includes more detailed information on
\end{abstract}

crop-specific fertilizer application practices and better accounts for meteorological modulation of $\mathrm{NH}_{3}$ emission factors in China. We find that annual anthropogenic $\mathrm{NH}_{3}$ emissions are $11.7 \mathrm{Tg}$ for 2008 , with $5.05 \mathrm{Tg}$ from fertilizer application and $5.31 \mathrm{Tg}$ from livestock waste. The two sources together account for $88 \%$ of total anthropogenic $\mathrm{NH}_{3}$ emissions in China. Our bottom-up emission estimates also show a distinct seasonality peaking in summer, consistent with topdown results from the satellite-based inversion. Further evaluations using surface network measurements show that the model driven by our bottom-up emissions reproduces the observed spatial and seasonal variations of $\mathrm{NH}_{3}$ gas concentrations and ammonium $\left(\mathrm{NH}_{4}^{+}\right)$wet deposition fluxes over China well, providing additional credibility to the improvements we have made to our agricultural $\mathrm{NH}_{3}$ emission inventory. 


\section{Introduction}

Ammonia $\left(\mathrm{NH}_{3}\right)$ and its aerosol-phase product ammonium $\left(\mathrm{NH}_{4}^{+}\right)$exert important influences on atmospheric chemistry and biodiversity. They contribute to formation of fine particulate matter (PM) that has adverse effects on air quality and visibility (Park et al., 2004; Lelieveld et al., 2015) and causes a cooling climatic forcing (Martin et al., 2004; Henze et al., 2012). Their deposition to nonagricultural ecosystems can further lead to soil acidification and eutrophication (Stevens et al., 2004; Bowman et al., 2008). Quantifying these environmental consequences requires accurate knowledge of $\mathrm{NH}_{3}$ sources, which are mainly associated with agricultural farming and livestock production (Bouwman et al., 1997). China, due to its intensive agricultural activities, is one of the largest $\mathrm{NH}_{3}$ emitting countries in the world. However, current estimates of Chinese agricultural $\mathrm{NH}_{3}$ emissions differ by more than a factor of 2 (see Sect. 2). Here we aim to better constrain agricultural $\mathrm{NH}_{3}$ emissions in China using available $\mathrm{NH}_{3}$ concentration and wet deposition flux measurements interpreted by the GEOS-Chem chemical transport model (CTM) and its adjoint.

As the main alkaline gas in the atmosphere, $\mathrm{NH}_{3}$ reacts with sulfuric acid $\left(\mathrm{H}_{2} \mathrm{SO}_{4}\right)$ and nitric acid $\left(\mathrm{HNO}_{3}\right)$, which are produced by the oxidation of sulfur dioxide $\left(\mathrm{SO}_{2}\right)$ and nitrogen oxides $\left(\mathrm{NO}_{x}\right)$, to form ammonium sulfate and ammonium nitrate aerosols, respectively. These secondary inorganic aerosols account for 40-57\% of the fine PM concentrations in eastern China (Yang et al., 2011; Huang et al., 2014). Recent studies also highlighted the possible role of $\mathrm{NH}_{3}$ in neutralizing aerosol $\mathrm{pH}$ that can strongly enhance formation of sulfate through heterogeneous oxidation of $\mathrm{SO}_{2}$ (Wang et al., 2016; Cheng et al., 2016; Paulot et al., 2016). All this evidence leads to increasing concerns that the effectiveness of $\mathrm{SO}_{2}$ and $\mathrm{NO}_{x}$ emission controls on fine PM pollution over China may be undermined by unregulated $\mathrm{NH}_{3}$ emissions (Wang et al., 2013; Fu et al., 2017).

Emissions of $\mathrm{NH}_{3}$ are generally estimated from bottomup statistical methods or process-based models by considering activity data and emission factors (emissions per unit activity) of all possible sources. The two most important $\mathrm{NH}_{3}$ sources are the application of synthetic fertilizers generated by the Haber-Bosch process (Erisman et al., 2008) and livestock production (volatilization of $\mathrm{NH}_{3}$ from animal excreta). They together are estimated to contribute $57 \%$ of global $\mathrm{NH}_{3}$ emissions (Bouwman et al., 1997) and $80 \%$ in Asia (Streets et al., 2003; Kurokawa et al., 2013). Bottomup $\mathrm{NH}_{3}$ emission estimates highly depend on the accuracy of activity data and emission factors that require detailed spatial and temporal information on local agricultural practices and environmental conditions as will be discussed in Sect. 2.

Inverse modeling methods provide top-down emission estimates through optimizing comparisons of model simulations with measurements (Gilliland et al., 2003, 2006; Pinder et al., 2006; Zhu et al., 2013; Paulot et al., 2014). Top-down estimates of $\mathrm{NH}_{3}$ emissions over China have been rare due to limited concentration or flux measurements of reduced nitrogen $\left(\mathrm{NH}_{x}=\right.$ gaseous $\mathrm{NH}_{3}+$ aerosol $\left.\mathrm{NH}_{4}^{+}\right)$. A previous inversion study by Paulot et al. (2014) used $\mathrm{NH}_{4}^{+}$wet deposition flux measurements from the Acid Deposition Monitoring Network in East Asia (EANET) that only included two sites in China over the study period. Satellite observations of atmospheric $\mathrm{NH}_{3}$ concentration have been emerging in recent years. These satellite instruments include the Tropospheric Emission Spectrometer (TES) (Beer et al., 2008; Shephard et al., 2011), the Infrared Atmospheric Sounding Interferometer (IASI) (Clarisse et al., 2009; Van Damme et al., 2015), the Atmospheric Infrared Sounder (AIRS) (Warner et al., 2016, 2017), and the Cross-track Infrared Sounder (CrIS) (Shephard and Cady-Pereira, 2015), providing increasingly rich datasets to understand the spatial and temporal variability of $\mathrm{NH}_{3}$ in the atmosphere.

In this study, we apply TES satellite observations of $\mathrm{NH}_{3}$ column concentration to provide top-down constraints on $\mathrm{NH}_{3}$ emissions in China for the year 2008 using the GEOSChem adjoint model at the $1 / 2^{\circ} \times 2 / 3^{\circ}$ horizontal resolution. In order to reconcile with the bottom-up estimates and to better understand inversion results, we construct a new bottomup inventory of Chinese agricultural $\mathrm{NH}_{3}$ emissions by using more practical fertilizer application rates and timing over different crop categories and by better considering the seasonal variability of emission factors. We further evaluate the topdown and the improved bottom-up Chinese $\mathrm{NH}_{3}$ emissions using an ensemble of surface measurements of $\mathrm{NH}_{3}$ gas concentration and $\mathrm{NH}_{4}^{+}$wet deposition flux.

\section{Previous bottom-up estimates of Chinese $\mathrm{NH}_{3}$ emissions}

We summarize in Table 1 published bottom-up estimates of Chinese $\mathrm{NH}_{3}$ emissions. Annual $\mathrm{NH}_{3}$ emissions from fertilizer application, livestock waste, human excrement, and other sources (e.g., transportation, waste disposal, industry) are presented from each inventory. Total anthropogenic $\mathrm{NH}_{3}$ emissions based on the years of 2005-2012 range from 8.4 to 18.3 teragram $(\mathrm{Tg}) \mathrm{NH}_{3}$ per annum $\left(\mathrm{a}^{-1}\right)$. The factor of 2 difference is not likely due to the different base years. Analyses of historical $\mathrm{NH}_{3}$ emissions in China show relatively stable or weak increasing trends (less than $3 \% \mathrm{yr}^{-1}$ ) since 2000 (Xu et al., 2016; Kang et al., 2016), consistent with trends in atmospheric $\mathrm{NH}_{3}$ concentration observed from satellites (Warner et al., 2017; Fu et al., 2017).

Fertilizer application and livestock waste are the two largest $\mathrm{NH}_{3}$ sources, together accounting for more than $82 \%$ of the total anthropogenic emissions over China (Table 1). However, considerable differences exist in their emission totals and relative importance. Estimates of $\mathrm{NH}_{3}$ emissions from fertilizer application in China range from $1.82 \mathrm{Tg} \mathrm{a}^{-1}$ in 2004 ( $\mathrm{Li}$ and $\mathrm{Li}, 2012$ ) to $9.82 \mathrm{Tg} \mathrm{a}^{-1}$ in 2010 (Zhao et al., 
Table 1. Bottom-up estimates of ammonia anthropogenic emissions in China ${ }^{1}$.

\begin{tabular}{|c|c|c|c|c|c|c|}
\hline References & $\begin{array}{l}\text { Base } \\
\text { year }\end{array}$ & $\begin{array}{c}\text { Fertilizer } \\
\text { application }\end{array}$ & $\begin{array}{l}\text { Livestock } \\
\text { waste }\end{array}$ & Human & Others $^{2}$ & Total \\
\hline Yan et al. (2003) & 1995 & 4.32 & $2.48^{3}$ & \multicolumn{2}{|c|}{0.21} & 7.01 \\
\hline Streets et al. (2003) & 2000 & 6.8 & 5.17 & \multicolumn{2}{|c|}{1.63} & 13.6 \\
\hline $\mathrm{Li}$ and $\mathrm{Li}(2012)$ & 2004 & 1.82 & 8.30 & 1.67 & 0.21 & 12.0 \\
\hline Wang et al. (2009) & 2005 & 4.3 & 8.82 & \multicolumn{2}{|c|}{0.26} & 13.38 \\
\hline Zhang et al. (2011) & 2005 & 4.31 & & & & \\
\hline Dong et al. (2010) & 2006 & 8.68 & 6.61 & 0.65 & 0.14 & 16.08 \\
\hline Huang et al. (2012) & 2006 & 3.2 & 5.3 & 0.2 & 1.1 & 9.8 \\
\hline Cao et al. (2010) & 2007 & 3.62 & \multicolumn{2}{|l|}{9.58} & 2.8 & 16.0 \\
\hline EDGAR & 2008 & 8.1 & 3.1 & \multicolumn{2}{|c|}{0.1} & 11.3 \\
\hline Xu et al. (2016) & 2008 & 3.3 & $3.8^{3}$ & 0.7 & 0.6 & 8.4 \\
\hline Paulot et al. (2014) (MASAGE) & 2008 & 3.6 & 5.8 & \multicolumn{2}{|c|}{0.8} & 10.2 \\
\hline Kurokawa et al. (2013) (REAS v2) & 2008 & 9.46 & 2.88 & 1.81 & 0.85 & 15.0 \\
\hline Zhao et al. (2013) & 2010 & 9.82 & 7.36 & \multicolumn{2}{|c|}{1.12} & 18.3 \\
\hline Fu et al. (2015) & 2011 & 3 & & & & \\
\hline Kang et al. (2016) & 2012 & 2.8 & 4.99 & 0.12 & 1.71 & 9.62 \\
\hline This study & 2008 & 5.05 & 5.31 & \multicolumn{2}{|c|}{$1.30^{4}$} & 11.7 \\
\hline
\end{tabular}

\footnotetext{
${ }^{1}$ Emission totals in unit of $\mathrm{Tg} \mathrm{NH}_{3} \mathrm{a}^{-1} .^{2}$ Others include sources from transportation, industry, waste disposal, and agricultural burning. ${ }^{3}$ Only considering $\mathrm{NH}_{3}$ emission from livestock manure spreading to cropland. ${ }^{4}$ Emission estimates adopted from Huang et al. (2012).
}

2013). All these emission estimates are calculated by multiplying fertilizer use amounts with corresponding volatilization rates (emission factors), except for Fu et al. (2015) that considered bi-directional $\mathrm{NH}_{3}$ fluxes over an agricultural model. Large differences are mainly due to uncertainties in $\mathrm{NH}_{3}$ emission factors that are highly sensitive to fertilizer types, local soil, and meteorological properties (Bouwman et al., 2002; Søgaard et al., 2002). $\mathrm{NH}_{3}$ emissions from livestock waste also range from 2.88 to $8.82 \mathrm{Tg} \mathrm{a}^{-1}$. An important uncertainty is also attributed to emission factors from livestock waste that heavily relied on European-based measurements in earlier estimates (Streets et al., 2003). Moreover, some estimates, e.g., Yan et al. (2003) (2.48 $\mathrm{Tg} \mathrm{a}^{-1}$ for 1995) and $\mathrm{Xu}$ et al. (2016) (3.8 $\mathrm{Tg} \mathrm{a}^{-1}$ for 2008), only accounted for livestock manure spreading to cropland and omitted contributions from animal housing and manure storage.

$\mathrm{NH}_{3}$ from humans, including latrines and human perspiration and respiration, is another source with considerable differences $\left(0.12-1.81 \mathrm{Tga}^{-1}\right)$. The major component of this source is from rural excrement stored in roughly constructed latrines without sewage service, with uncertainties in estimates of rural population and the associated $\mathrm{NH}_{3}$ emission factor. Other sources, such as agricultural burning, transportation, waste disposal, and industry also contribute $0.14-2.8 \mathrm{Tg} \mathrm{NH}_{3} \mathrm{a}^{-1}$, depending on inclusions of different source sectors in the emission inventories. For example, Dong et al. (2010) $\left(0.14 \mathrm{Tg} \mathrm{a}^{-1}\right)$ only estimated $\mathrm{NH}_{3}$ emitted from the chemical industry. These sources are relatively small compared to agricultural sources of fertilizer ap- plication and livestock waste at the national scale; however, recent studies show that fuel combustion, (Pan et al., 2016), transportation (Chang et al., 2016; Sun et al., 2017), or local green space (Teng et al., 2017) can be dominant sources of $\mathrm{NH}_{3}$ in the urban atmosphere.

We find substantial differences in spatial and seasonal variations of $\mathrm{NH}_{3}$ emissions among the inventories. Figure 1 compares spatial distributions of anthropogenic $\mathrm{NH}_{3}$ emissions in China from four commonly used inventories: the Regional Emission in Asia (REAS v2) inventory (Kurokawa et al., 2013), the Streets et al. (2003) inventory, the Huang et al. (2012) inventory, and the Emission Database for Global Atmospheric Research (EDGAR) (Olivier and Berdowski, 2001). Although they all show higher $\mathrm{NH}_{3}$ emission rates in the east than the west, with the highest emissions occurring over North China, there are distinct regional differences of 50-200\%. In particular, EDGAR shows much more evenly distributed $\mathrm{NH}_{3}$ emission rates spreading over China than the other three inventories.

Figure 1 also shows seasonal variations in these Chinese $\mathrm{NH}_{3}$ emissions. Some inventories such as EDGAR and REAS v2 do not consider the seasonality of $\mathrm{NH}_{3}$ emissions due to a lack of reliable information. More recent estimates account for information on the timing of fertilizer application and influences of meteorology on $\mathrm{NH}_{3}$ emission factors. We can see that Huang et al. (2012) suggest a weak summer peak in Chinese $\mathrm{NH}_{3}$ emissions, while the MASAGE inventory (Paulot et al., 2014) indicates largest emissions in April and July. $\mathrm{NH}_{3}$ emission estimates of Streets et al. (2003) have a strong peak in June and are much higher than Huang 

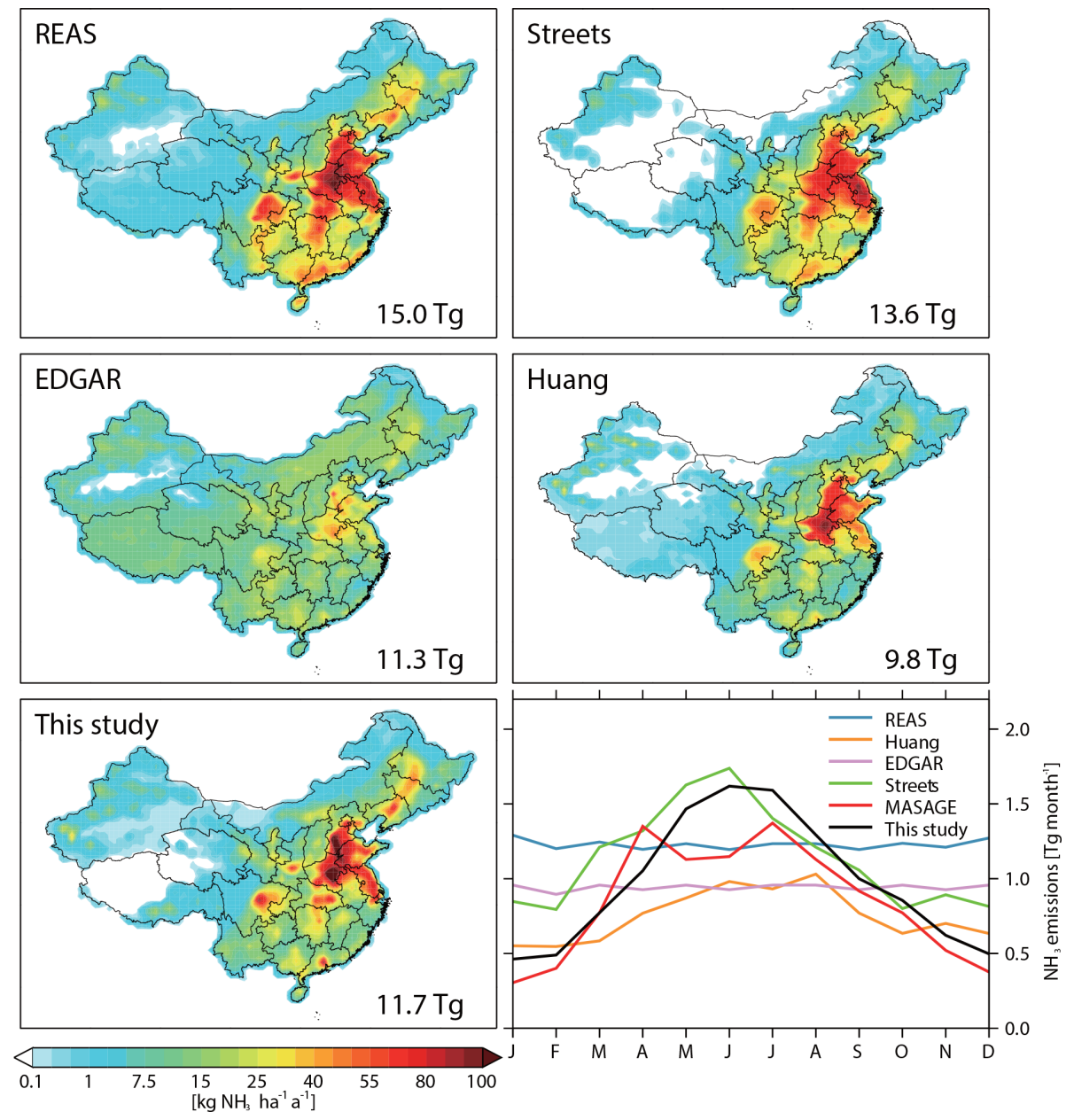

Figure 1. Spatial and seasonal variations of anthropogenic $\mathrm{NH}_{3}$ emissions in China from different bottom-up inventories. Numbers inset are annual totals of Chinese anthropogenic $\mathrm{NH}_{3}$ emissions. See Table 1 for references of the emission inventories.

et al. (2012) and Paulot et al. (2014) in winter. All these discrepancies as discussed above emphasize the need to improve our understanding of Chinese $\mathrm{NH}_{3}$ emissions in light of measurements of $\mathrm{NH}_{3}$ gas concentration and deposition flux.

\section{Model description}

\subsection{The GEOS-Chem model}

Here we will use the GEOS-Chem CTM and its adjoint to simulate the sources and sinks of $\mathrm{NH}_{3}$ over China. GEOSChem is a global 3-D tropospheric chemistry model (http: //geos-chem.org) driven by assimilated meteorological data from the Goddard Earth Observing System (GEOS) of the NASA Global Modeling and Assimilation Office (GMAO). The GEOS-5 meteorological data have a horizontal resolution of $1 / 2^{\circ}$ latitude $\times 2 / 3^{\circ}$ longitude and a temporal resolution of $3 \mathrm{~h}$ ( $1 \mathrm{~h}$ for surface variables). We apply here a one-way nested-grid version of GEOS-Chem with the native $1 / 2^{\circ} \times 2 / 3^{\circ}$ horizontal resolution over East Asia (70- $\left.140^{\circ} \mathrm{E}, 15-55^{\circ} \mathrm{N}\right)$ and $2^{\circ} \times 2.5^{\circ}$ over the rest of the world (Wang et al., 2004; Chen et al., 2009).

The model simulates a detailed tropospheric ozone$\mathrm{NO}_{x}$-hydrocarbon-aerosol chemistry as described by Park et al. (2004) and Mao et al. (2010). $\mathrm{NH}_{3}$ in the atmosphere is partitioned to gas and aerosol phases based on the Regional Particulate Model Aerosol Reacting System (RPMARES) thermodynamic equilibrium model (Binkowski and Roselle, 2003). $\mathrm{NH}_{3}$ is thermodynamically favored to combine with $\mathrm{H}_{2} \mathrm{SO}_{4}$ to form ammonium bisulfate and ammonium sulfate, and excessive $\mathrm{NH}_{3}$ can react with $\mathrm{HNO}_{3}$ to form ammonium nitrate. GEOS-Chem simulations of secondary inorganic aerosols (ammonium, sulfate, and nitrate) over China have been validated by Wang et al. (2013) and Li et al. (2016) recently; both show high sensitivity of simulated nitrate concentrations to $\mathrm{NH}_{3}$ emissions. GEOS-Chem also includes the ISORROPIA II thermodynamic equilibrium model (Fountoukis and Nenes, 2007). We find that differences in simulated monthly $\mathrm{NH}_{3}$ concentrations over China by the two 
equilibrium models are less than 5\%, and RPMARES runs about $30 \%$ faster in the GEOS-Chem adjoint.

The model wet deposition scheme is described by Liu et al. (2001) with updates from Amos et al. (2012) for soluble gases and Wang et al. (2011) for aerosols. It includes convective updraft scavenging as well as largescale precipitation rainout and washout. Uptake of gaseous $\mathrm{NH}_{3}$ is estimated following Henry's law in warm clouds ( $T>268 \mathrm{~K}$ ), using a retention efficiency of 0.05 in mixedphase clouds $(248<T<268 \mathrm{~K})$ and zero efficiency in cold clouds $\left(T<248 \mathrm{~K}\right.$ ) (Wang et al., 2008), while aerosol $\mathrm{NH}_{4}^{+}$ is fully incorporated in all clouds. Dry deposition calculation follows a standard resistance-in-series model as described by (Wesely, 1989) for gases and Zhang et al. (2001) for aerosols.

We use the EDGAR global anthropogenic emissions overwritten by regional emission inventories including the US EPA 2005 National Emissions Inventory (NEI-2005), the European Monitoring and Evaluation Programme (EMEP) emissions, and the Canada Criteria Air Contaminants (CAC) inventory. Asian anthropogenic emissions are from Zhang et al. (2009) except for $\mathrm{NH}_{3}$ as described below. These global and regional inventories are scaled to the simulation year of 2008 using the energy statistics as implemented by van Donkelaar et al. (2008). For the prior $\mathrm{NH}_{3}$ emissions, we use the REAS v2 emission inventory that does not consider any seasonal variation (Kurokawa et al., 2013) so that the inverted emission seasonality is solely from satellite observations. We also follow Zhu et al. (2013) and increase $\mathrm{NH}_{3}$ emissions from fertilizer use and livestock by $90 \%$ in the daytime and reduce them by $90 \%$ at night to account for their diurnal variability. Natural sources of $\mathrm{NH}_{3}$ and $\mathrm{NO}_{x}$ from biomass burning, soil, and lightning follow the settings of Zhao et al. (2015) and are relatively small over China (0.56 Tg NH $\mathrm{Na}^{-1}$; Zhao et al., 2017).

\subsection{The GEOS-Chem adjoint}

We use the adjoint of GEOS-Chem to optimize Chinese $\mathrm{NH}_{3}$ emissions through assimilation of TES $\mathrm{NH}_{3}$ column measurements as will be discussed in the next section. The model adjoint is first described by Henze et al. (2007) for aerosols and Kopacz et al. (2009) for carbon monoxide. It has been highly validated and applied in studies to analyze aerosol sensitivities and constrain aerosol sources in the United States (Henze et al., 2009; Zhu et al., 2013; Mao et al., 2015) and China (Kharol et al., 2013; Zhang et al., 2015, 2016; Qu et al., 2017).

The emission optimization is conducted by minimizing the cost function $(J)$, defined as

$$
\begin{aligned}
J(\boldsymbol{x})= & \left(Y(\boldsymbol{x})-\boldsymbol{y}_{\mathrm{obs}}\right)^{\mathrm{T}} \mathbf{S}_{\mathrm{e}}^{-1}\left(Y(\boldsymbol{x})-\boldsymbol{y}_{\mathrm{obs}}\right) \\
& +(\boldsymbol{\sigma}-1)^{\mathrm{T}} \mathbf{S}_{\mathrm{a}}^{-1}(\boldsymbol{\sigma}-1),
\end{aligned}
$$

where $\boldsymbol{y}_{\text {obs }}$ is the vector of satellite observations, $\boldsymbol{x}$ is the vector of $\mathrm{NH}_{3}$ emissions in the model, $Y(\boldsymbol{x})$ represents simulated $\mathrm{NH}_{3}$ concentration for comparison with $\boldsymbol{y}_{\mathrm{obs}}, \boldsymbol{x}_{\mathrm{a}}$ is the vector of a priori emissions, $\sigma$ is the vector of scaling factors $\left(\boldsymbol{x} / \boldsymbol{x}_{\mathrm{a}}\right)$ for optimizing, and $\mathbf{S}_{\mathrm{a}}$ and $\mathbf{S}_{\mathrm{e}}$ are the a priori and observational error covariance matrices, respectively. Zhu et al. (2013) have previously applied the adjoint inverse model assimilating TES $\mathrm{NH}_{3}$ data to constrain US $\mathrm{NH}_{3}$ emissions, and Paulot et al. (2014) used wet $\mathrm{NH}_{x}$ deposition data to constrain East Asian $\mathrm{NH}_{3}$ emissions, both at a coarser $2^{\circ} \times 2.5^{\circ}$ model resolution.

The adjoint model computes the gradient of the cost function $\left(\nabla_{x} J\right)$ numerically, and applies the quasi-Newton LBFGS-B algorithm (Byrd et al., 1995) to minimize the cost function iteratively. It usually takes about 15 iterations to reach the convergence, identified as the iteration when the cost function decreases by less than $2 \%$ relative to the prior one. To lower the computational expenses, we follow the approach of Paulot et al. (2014) and use an offline $\mathrm{NH}_{x}\left(\mathrm{NH}_{3}+\mathrm{NH}_{4}^{+}\right)$simulation for the adjoint inversion that only calculates the physical and chemical transformation of $\mathrm{NH}_{x}$ driven by hourly simulated sulfate and total nitrate $\left(\mathrm{HNO}_{3}+\mathrm{NO}_{3}^{-}\right)$concentrations archived from the standard simulation (Sect. 3.1). This approach would induce errors by not accounting for changes in total nitrate concentrations when $\mathrm{NH}_{3}$ emissions change (Paulot et al., 2014). We find that a $30 \%$ increase of Asian $\mathrm{NH}_{3}$ emissions would increase the total nitrate concentration by about $10 \%$, but deviations of $\mathrm{NH}_{3}$ concentrations in the offline simulation from the standard simulation due to the $\mathrm{NH}_{3}$ emission change are less than $3 \%$ over China.

\section{Adjoint inversion of Chinese $\mathrm{NH}_{3}$ emissions with satellite observations}

We use satellite observations of $\mathrm{NH}_{3}$ column concentration over China retrieved from TES, a high spectral resolution Fourier transform infrared spectrometer aboard the NASA Aura satellite launched in July 2004 (Beer et al., 2006). TES observations have a spatial resolution of $5 \mathrm{~km} \times 8 \mathrm{~km}$ at nadir with a local crossing time of 01:30 and 13:30 LT and global coverage achieved every 16 days (Beer et al., 2008; Shephard et al., 2011). TES retrievals of atmospheric $\mathrm{NH}_{3}$ concentration are estimated by the optimal estimation method as described in Shephard et al. (2011). We filter the TES $\mathrm{NH}_{3}$ retrievals by only using daytime observations with degree of freedom for signal (DOFS) greater than 0.1 . We also correct the positive biases $(0.04-1.0 \mathrm{ppbv}$ in the lower troposphere depending on the a priori profile type used in the retrieval) in TES $\mathrm{NH}_{3}$ retrievals following Zhu et al. (2013). Available TES observations for assimilation then become very spatially sparse for a single month. We assemble TES observations over the years of 2005-2010 for better spatial data coverage. AIRS $\mathrm{NH}_{3}$ observations over 2002-2015 show weak increasing trends $\left(2.27 \% \mathrm{yr}^{-1}\right)$ over Chinese agricultural areas.

Figure 2 shows TES-observed $\mathrm{NH}_{3}$ column concentrations with a footprint size of $5 \mathrm{~km} \times 8 \mathrm{~km}$ from March to 

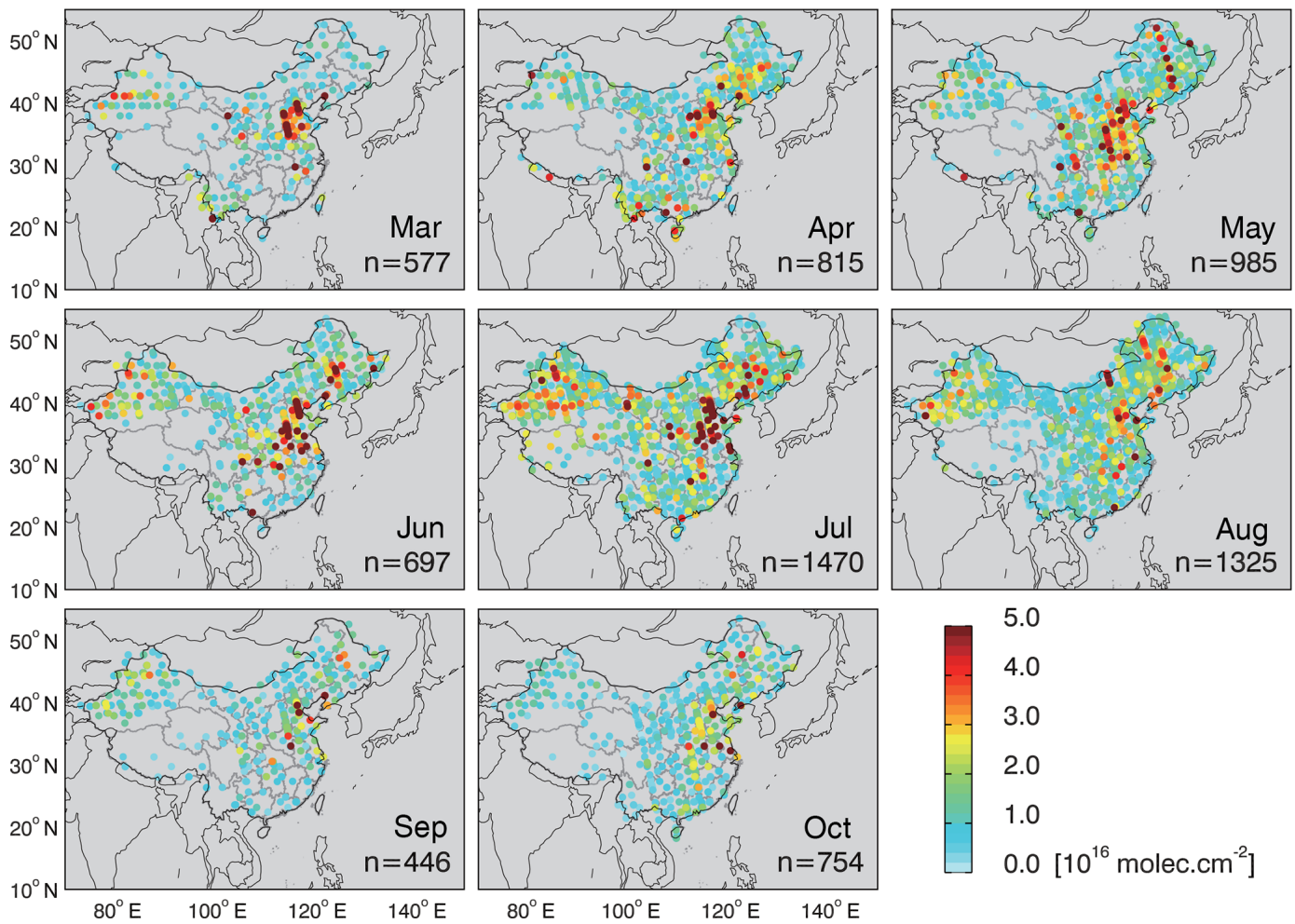

Figure 2. TES observations of $\mathrm{NH}_{3}$ column concentration over China from March to October in the years 2005-2010. Each point represents a TES observation with a footprint resolution of $5 \mathrm{~km} \times 8 \mathrm{~km}$. Values inset are number $(n)$ of valid observations for assimilation in each month.

October. We do not analyze the late fall and winter months (November-February) as the valid TES observations become very limited, which hinders a reliable emission inversion in those months. As can be seen in Fig. 2, the largest $\mathrm{NH}_{3}$ column concentrations are observed over North China, reflecting intensive agricultural activities over this area. High $\mathrm{NH}_{3}$ concentrations are also observed over the province of Xinjiang in Northwest China, which are likely emitted from animal grazing and remain mainly in gas phase due to lower $\mathrm{NO}_{x}$ and $\mathrm{SO}_{2}$ emissions to generate acids there. TES observations show a strong seasonality, with the national averaged $\mathrm{NH}_{3}$ column concentration a factor of 2 higher in summer than spring, similar to other satellite $\mathrm{NH}_{3}$ observations retrieved from AIRS (Warner et al., 2017) and IASI (Van Damme et al., 2015).

We now assimilate TES-observed $\mathrm{NH}_{3}$ columns into the model through minimizing the cost function defined by Eq. (1). The emission optimization is conducted for each month of March-October 2008. Model results are sampled along the satellite orbits and then processed with TES a priori profiles and averaging kernel matrices as a necessary process for comparing with satellite retrievals based on the optimal estimation method (L. Zhang et al., 2010; Zhu et al., 2013). For the error covariance matrices, we assume the a priori error covariance $\left(\mathbf{S}_{\mathrm{a}}\right)$ to be diagonal and the uncertainties to be
$100 \%$. The observational error covariance $\left(\mathbf{S}_{\mathrm{obs}}\right)$ is assumed to be $40 \%$ of averaged values of observations and model results, accounting for uncertainties in both observations and the model. We have also conducted sensitivity inversions by using different $\mathbf{S}_{\mathrm{a}}(50$ and $200 \%)$ or $\mathbf{S}_{\mathrm{e}}(20$ and $60 \%)$ for the month of July.

Figure 3 shows differences between TES-observed and model-simulated $\mathrm{NH}_{3}$ column concentrations with both the prior and optimized $\mathrm{NH}_{3}$ emissions over China for April, July, and October. It also shows the correction ratios of optimized emissions over the prior emissions (REAS v2 in Fig. 1). We can see that with the prior Chinese $\mathrm{NH}_{3}$ emissions, model results largely underestimate TES observations in July with a mean bias of $-47 \%$, while they overestimate observations in April and October by 10-35\%. Model results with optimized $\mathrm{NH}_{3}$ emissions improve comparison correlation coefficients (from $0.25-0.55$ to $0.49-0.63$ ) and significantly reduce the mean biases $(-8-0 \%)$. For these inversions, the cost functions are generally reduced by $35-45 \%$.

The emission correction ratios reflect seasonally and spatially heterogeneous adjustments. Ratios in July show overall increases over China by factors of $1.5-3$ except for some locations over Northeast China. In April and October, there are large decreases (up to $70 \%$ ) over North China and Central China, while increases are noted in Southeast 
(a)
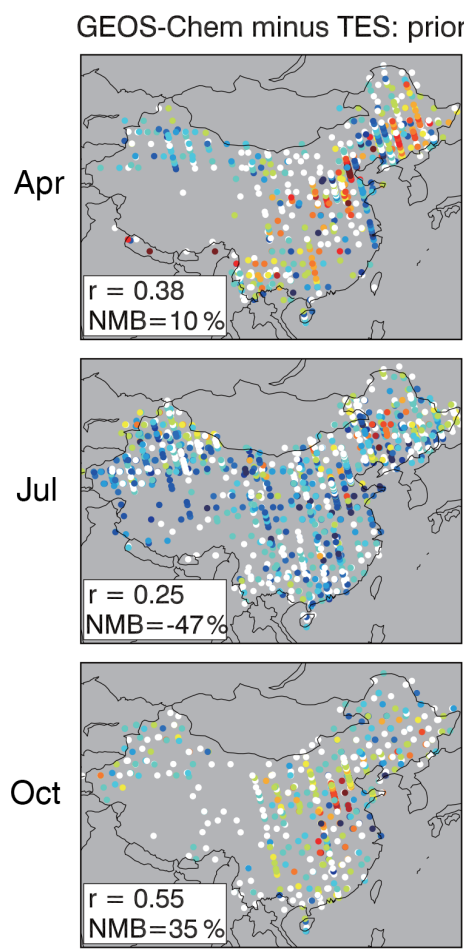

(b)

Optimized
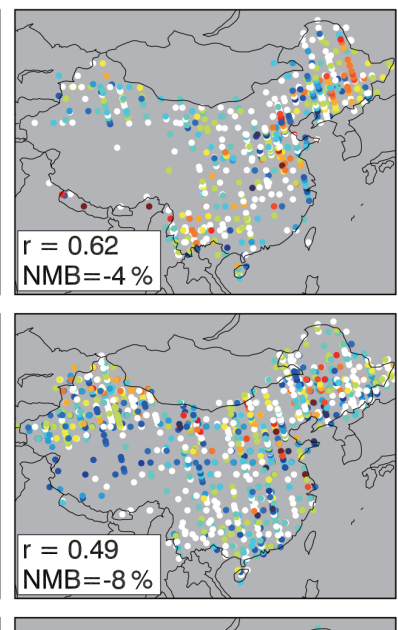

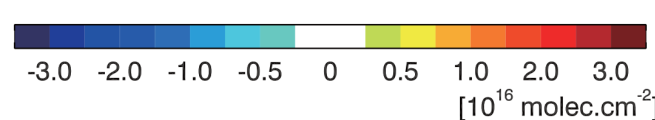

(c)

Emission ratio (optimized/prior)
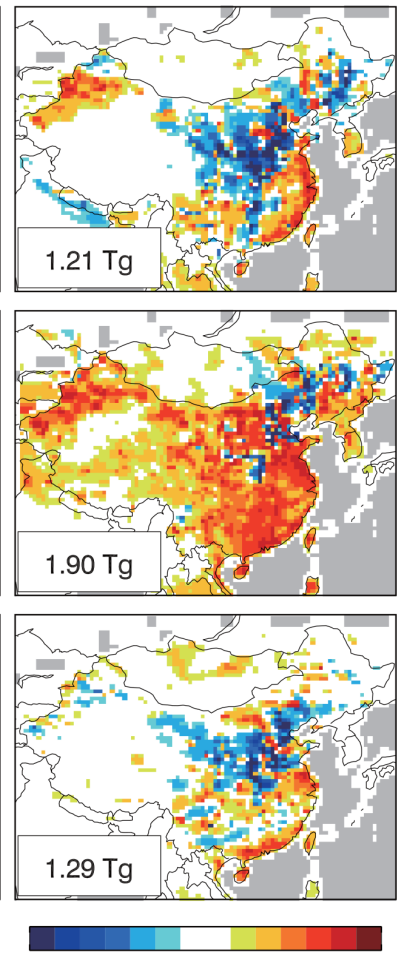

$\begin{array}{lllllll}0.4 & 0.6 & 0.9 & 1 & 1.3 & 1.5 & 3.0\end{array}$

Figure 3. Differences between GEOS-Chem-simulated and TES-observed $\mathrm{NH}_{3}$ column concentrations over China for April, July, and October. Panels $(\mathbf{a}, \mathbf{b})$ show results from model simulations with prior and optimized $\mathrm{NH}_{3}$ emissions, respectively. Correlation coefficients $(r)$ and normalized mean biases (NMB) are shown inset. Panel (c) shows monthly correction ratios relative to the prior emissions with optimized Chinese emission amounts shown inset.

China. Large emission increases are also shown over Northwest China in April and July. The optimized Chinese anthropogenic $\mathrm{NH}_{3}$ emissions in July (1.90 Tg month ${ }^{-1}$ ) are $47-57 \%$ higher than April $\left(1.21 \mathrm{Tg}_{\mathrm{month}}^{-1}\right)$ and October $\left(1.29 \mathrm{Tg}\right.$ month $\left.^{-1}\right)$. Inversion results for March-October indicate that Chinese $\mathrm{NH}_{3}$ emissions peak in summer (see Fig. 7). Similar to previous work of Mao et al. (2015), we also find that the top-down results can be moderately affected by the selection of a priori and observational error covariance matrices. Sensitivity inversions with different $\mathbf{S}_{\mathrm{a}}$ (50 and $200 \%)$ or $\mathbf{S}_{\mathrm{e}}(20$ and $60 \%$ ) for July show a range of 1.60-1.93 Tg month ${ }^{-1}$, with higher $\mathbf{S}_{\mathrm{a}}$ and lower $\mathbf{S}_{\mathrm{e}}$ values giving higher July emission estimates.

\section{Improving bottom-up estimates of agricultural $\mathrm{NH}_{3}$ emissions}

The top-down estimates presented above show a stronger summer peak in Chinese $\mathrm{NH}_{3}$ emissions than those represented in current bottom-up emission inventories (Fig. 1). Reconciling the discrepancy then requires us to better un- derstand the bottom-up emissions from the underlying processes. Previous studies have shown that $\mathrm{NH}_{3}$ emissions are highly sensitive to the magnitude and timing of fertilizer application as well as variations of meteorology (Søgaard et al., 2002; Gyldenkærne et al., 2005; Paulot et al., 2014), but these factors are neither sufficiently represented nor well evaluated in the Chinese $\mathrm{NH}_{3}$ emission estimates. Here we construct an improved bottom-up Chinese $\mathrm{NH}_{3}$ emission inventory from fertilizer application and livestock waste, with the objective to better estimate fertilizer application practices and emission factors. Figure 4 shows the schematic diagram of the bottom-up methodology as will be described in detail below.

\section{1 $\mathrm{NH}_{3}$ emission from fertilizer application}

The MASAGE inventory recently developed by Paulot et al. (2014) provides spatial-resolved and crop-specific estimates of fertilizer application practices over the globe. We follow the methodology of MASAGE for $\mathrm{NH}_{3}$ from fertilizer application but include detailed refinements for China. $\mathrm{NH}_{3}$ emissions from fertilizer application $\left(E_{\mathrm{NH}_{3}-\mathrm{F}}\right)$ are calculated as the product of synthetic fertilizer application mag- 


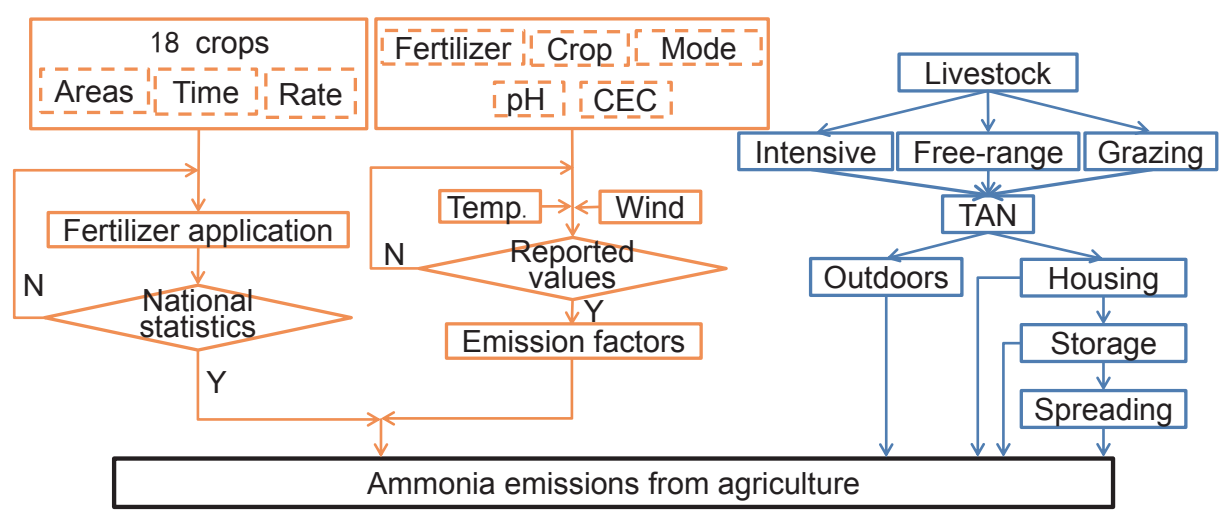

Figure 4. Schematic diagram for estimating agricultural $\mathrm{NH}_{3}$ emissions from fertilizer application and livestock waste.

nitude $(F)$ and corresponding emission factors $\left(\alpha_{\mathrm{F}}\right)$ :

$E_{\mathrm{NH}_{3}-\mathrm{F}}=F \times \alpha_{\mathrm{F}}$.

\subsubsection{Fertilizer application magnitude}

We estimate fertilizer application amounts for 18 crop categories (including early/late rice, spring/winter wheat, spring/summer maize, cotton, potato, and others as shown in Fig. 5). The fertilizer application magnitude $(F)$ is calculated as

$F=\sum_{\mathrm{c}} A_{\mathrm{c}} \times \Psi_{c}(t)$,

where $A_{\mathrm{c}}$ is the planting area of crop $c$, and $\psi$ represents fertilizer application rate at time $t$ (day of the year). We use the EarthStat dataset of crop harvest area (Monfreda et al., 2008; EarthStat, 2015), which provides global crop harvest areas and yields at $5 \mathrm{~min} \times 5 \mathrm{~min}$ resolution for the year 2000 . Here we regrid them to the model $1 / 2^{\circ} \times 2 / 3^{\circ}$ resolution, and scale the harvest area for each of the 18 crop categories to the year 2008 using the province-level data from the National Bureau of Statistics of China (NBSC, 2015). We use the harvest areas as the crop-planting areas except for rice and tobacco. Their planting areas are about $5 \%$ of the harvest areas during the seeding period, and then they move to the transplanting fields till harvest.

Estimating the fertilizer application rate $\Psi_{\mathrm{c}}(t)$ requires consideration of the planting schedule and fertilizer application practice for each crop. Paulot et al. (2014) distribute the annual fertilizer application amount over three stages (at planting, at growth, and after harvest) by assuming cropspecific application ratios. Here we consider much more detailed fertilizer application practices over China. Each crop requires the basal fertilizer applied at planting and several top dressing fertilizers during its growth (up to five application times). We construct tables of the fertilizer dates and rates (Tables S1 and S2 in the Supplement) for the main crop categories in China based on Liao (1993) and Zhang and Zhang (2012). The timing of fertilizer application to each crop is based on its planting date or the calendar day (Table S1). We use the crop-planting dates of Sacks et al. (2010). Following Paulot et al. (2014), a Gaussian distribution function (Gyldenkærne et al., 2005) is applied to account for uncertainties and interannual variations of application dates:

$F(t)=F \times \frac{1}{\sigma_{\mathrm{c}} \sqrt{2 \pi}} \times e^{\left(\frac{\left(t-\mu_{\mathrm{c}}\right)^{2}}{-2 \sigma_{\mathrm{c}}^{2}}\right)}$,

where $\mu_{\mathrm{c}}$ is the crop-specific fertilizer application date, and $\sigma_{\mathrm{c}}$ is the deviation from the mean planting date estimated from the dataset of Sacks et al. (2010) as summarized in Table S1.

The procedures above allow us to estimate fertilizer application rates for each calendar day for the main crops listed in Tables S1 and S2, and we sum them up at the monthly scale. Fertilizers applied through the injection and broadcast modes are estimated separately. Based on fertilizer application practices, the first fertilizer application at plant is typically through injection (for rice and tobacco the first applications at both seeding and transplanting fields) and the rest by broadcast. For other crops, fruits, and vegetables, we use the annual fertilizer use amounts from the International Fertilizer Industry Association (IFA, 2013) and NBSC (2015), and then we distribute them spatially using the crop yield data of EarthStat (2015) and apply monthly variations proportional to the number of daylight hours following Park et al. (2004).

Figure 5 shows seasonal variations of fertilizer application to each crop category in China through injection and broadcast, separately. We estimate that $9.2 \mathrm{Tg} \mathrm{Na}^{-1}$ fertilizers are used through injection and $15.8 \mathrm{Tg} \mathrm{Na}^{-1}$ through broadcast. They show strong but different seasonal variations as resulted from variations of application timings for different crop categories. The use of injected fertilizers peaks in spring (April and May) and has a second peak in fall mainly due to winter wheat, while the use of broadcast fertilizers maximizes in late spring and summer. The annual total fertilizer applica- 

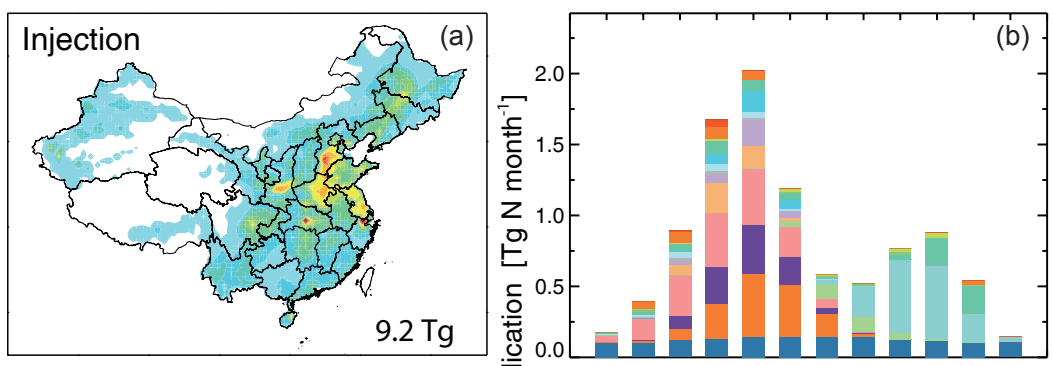

Rapeseed

- Tobacco

- Pear

Citrus

- Grape

- Banana

- Apple

Groundnut

- Soybean

- Spring wheat
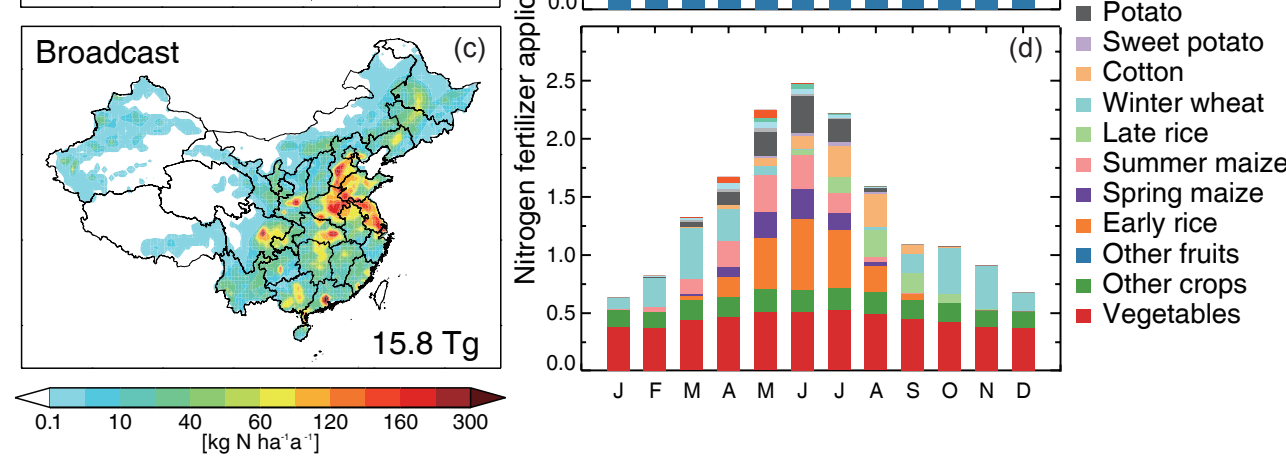

Figure 5. Fertilizer application through injection (a, b) and broadcast (c, d) techniques in China for 2008. Panels (a, c) show annual total fertilizer application at the $1 / 2^{\circ} \times 2 / 3^{\circ}$ model resolution with the annual totals given inset. Panels (b, d) show monthly fertilizer application amounts over China for the 18 crop types.

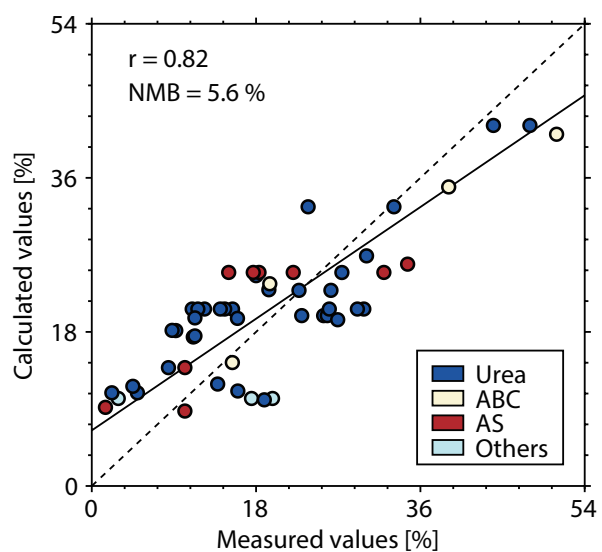

Figure 6. Comparison of calculated (using Eq. 5 in the text) and measured $\mathrm{NH}_{3}$ emission factors from application of different fertilizers: urea, ammonium bicarbonate $(\mathrm{ABC})$, ammonium sulfate (AS), and others in China. The correlation coefficient and normalized mean bias (NMB) are shown inset. Measurements of $\mathrm{NH}_{3}$ emission factors are summarized in Table S4 in the Supplement.

tion is estimated to be $25.0 \mathrm{Tg} \mathrm{N}$, compared with $22.4 \mathrm{Tg} \mathrm{N}$ in Huang et al. (2012) for 2006 and the FAO (Food and Agriculture Organization of the United Nations) estimate of $28.5 \mathrm{Tg} \mathrm{N}$ for 2008 (FAOSTAT, 2015).

\subsubsection{Emission factor from fertilizer application}

We estimate emission factors of $\mathrm{NH}_{3}$ from fertilizer application as a function of soil properties and agricultural activity information and further modulated by meteorological conditions (Paulot et al., 2014). The emission factor is first calculated as

$\alpha_{0}=e^{f_{\mathrm{pH}}+f_{\mathrm{CEC}}+f_{\mathrm{type}}+f_{\text {crop }}+f_{\text {mode }}}$,

where the factors $(f)$ represent effects of soil $\mathrm{pH}$, cation exchange capacity (CEC), fertilizer type (e.g., urea, ammonium bicarbonate (ABC), ammonium sulfate (AS)), and application mode (broadcast and injection) on $\mathrm{NH}_{3}$ volatilization mainly based on Bouwman et al. (2002) (Table S3 in the Supplement). Monthly scalars are then applied to account for the seasonality driven by meteorology:

$\alpha_{F}=\alpha_{0}\left(e^{0.0223 T_{i}+0.0419 W_{i}}\right) /\left(\frac{1}{12} \sum_{j=1}^{12} e^{0.0223 T_{j}+0.0419 W_{j}}\right)$,

where $T_{i}$ and $W_{i}$ are $2 \mathrm{~m}$ (meter) air temperature in ${ }^{\circ} \mathrm{C}$ and $10 \mathrm{~m}$ wind speed in $\mathrm{m} \mathrm{s}^{-1}$ for month $i$, respectively (Søgaard et al., 2002; Gyldenkærne et al., 2005).

We use the gridded $\left(0.5^{\circ} \times 0.5^{\circ}\right)$ soil $\mathrm{pH}$ data from the University of Wisconsin Nelson Institute Center for Sustainability and the Global Environment (SAGE, 2015), and the soil CEC data $\left(0.5^{\circ} \times 0.5^{\circ}\right)$ from the ISRIC-World Soil Information (ISRIC WSI, 2015) of the World Data Center for Soils. Crop categories and application modes follow the calculation of fertilizer application rates as described 


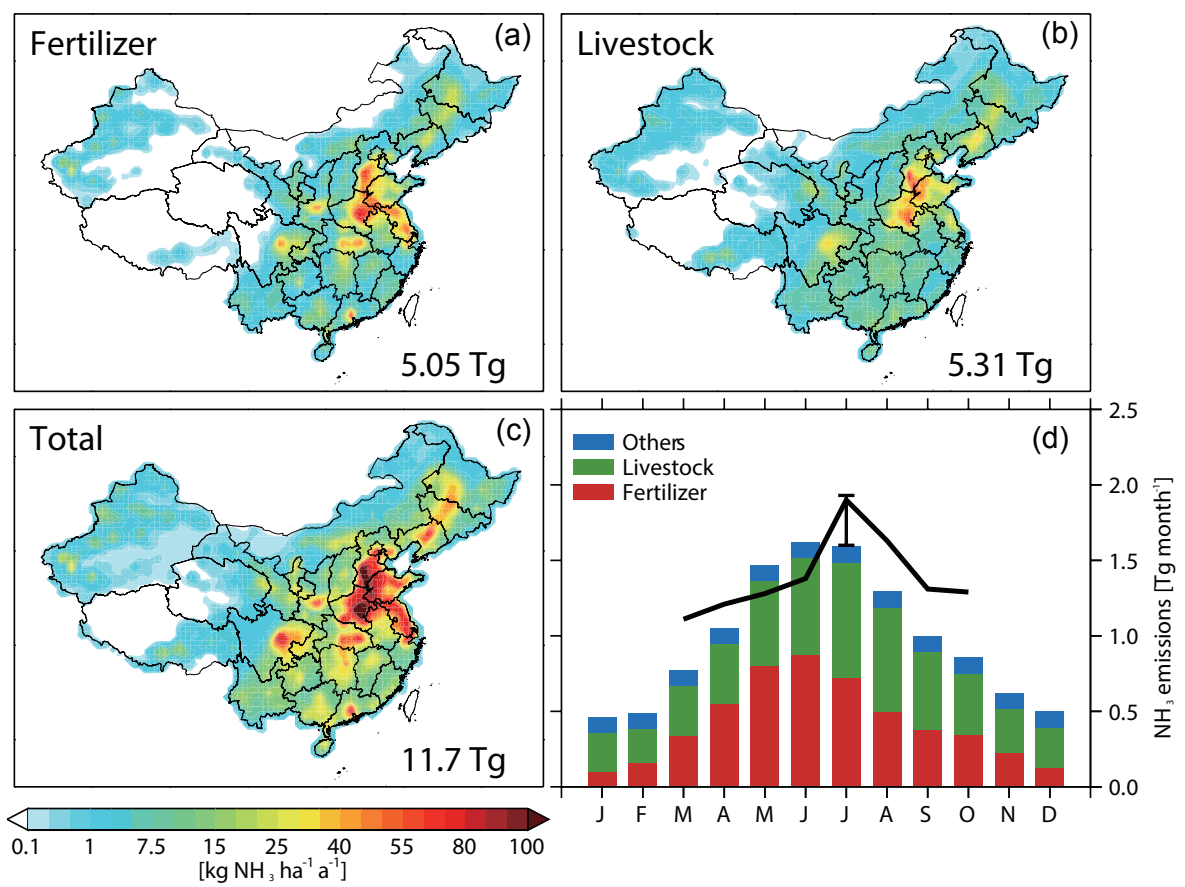

Figure 7. Improved bottom-up $\mathrm{NH}_{3}$ emission estimates from fertilizer use (a), livestock (b), and total anthropogenic emissions (c) in China. Values inset are emission totals. Panel (d) shows seasonal variations in Chinese $\mathrm{NH}_{3}$ emissions from different source categories. The bars represent our bottom-up estimates and the black line shows adjoint optimized anthropogenic totals for March-October. The vertical black line denotes the range of top-down estimates from inversions with different error configurations for the July month as described in the text.

above. Percentages of different fertilizer types applied to cropland are estimated based on the statistics from Zhang and Zhang (2012).

We have collected an ensemble of published measurements of $\mathrm{NH}_{3}$ emission factors (volatilization rates) from fertilizer application that cover different regions of China and consider different fertilizer types and application modes, as summarized in Table S4 in the Supplement. We compare these measurements with corresponding emission factors derived by Eq. (5). This comparison does not include meteorological effects (Eq. 6) due to a lack of relevant measurements for the published emission factors. As shown in Fig. 6, calculated and measured values are in good agreement with a correlation coefficient of 0.80 and a mean bias of $10 \%$, supporting calculations of $\mathrm{NH}_{3}$ emission factors using Eq. (5) for fertilizer application practices in China.

\subsection{Livestock waste}

The Chinese $\mathrm{NH}_{3}$ emissions from livestock waste are commonly derived as the product of livestock population and emission factors (Streets et al., 2003; Paulot et al., 2014). Here we follow Huang et al. (2012) and Kang et al. (2016) that adopted a more process-based mass-flow approach by considering the transformation of nitrogen in animal husbandry. As shown in Fig. 4, a pool of total ammoniacal nitrogen (TAN) as input to manure management is estimated by animal excreta from three main raising systems (free-range, intensive, and grazing). We use the gridded livestock (e.g., pork, beef, dairy, sheep, poultry) population from the Gridded Livestock of the World (GLW, 2015), and then we adjust them to match the province-level annual records of NBSC (2015) for 2008. The parameters of annual TAN excretion per animal considering both urine and feces and their nitrogen contents for each livestock category are given in Huang et al. (2012).

We estimate the content of TAN produced outdoors and indoors separately by assuming percentages of time spent outside and inside buildings for each livestock category (Huang et al., 2012). The outdoor TAN is directly deposited in the open air, while the indoor TAN can flow through the stages of housing, storage, and spreading to cropland as basal fertilizer with depletion of TAN from processes such as immobilization and leaching at each stage. $\mathrm{NH}_{3}$ emissions from livestock are calculated as the product of TAN at the four stages and corresponding emission factors. We use the emission factors of Huang et al. (2012) and further account for the meteorological influences as represented by Eq. (6). We consider both air temperature and wind speed for outdoor $\mathrm{NH}_{3}$ emissions, while we only account for air temperature for indoor emissions. Monthly emission factors are calculated using the GEOS-5 assimilated meteorological data at the model $1 / 2^{\circ} \times 2 / 3^{\circ}$ resolution . 
(a)
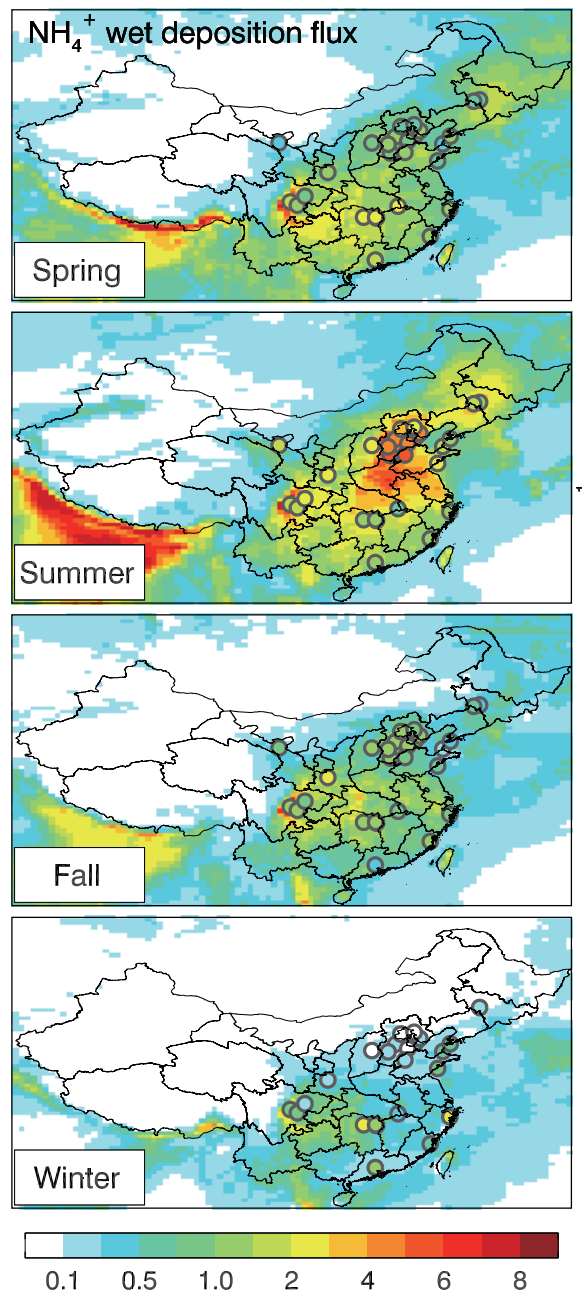

(b)

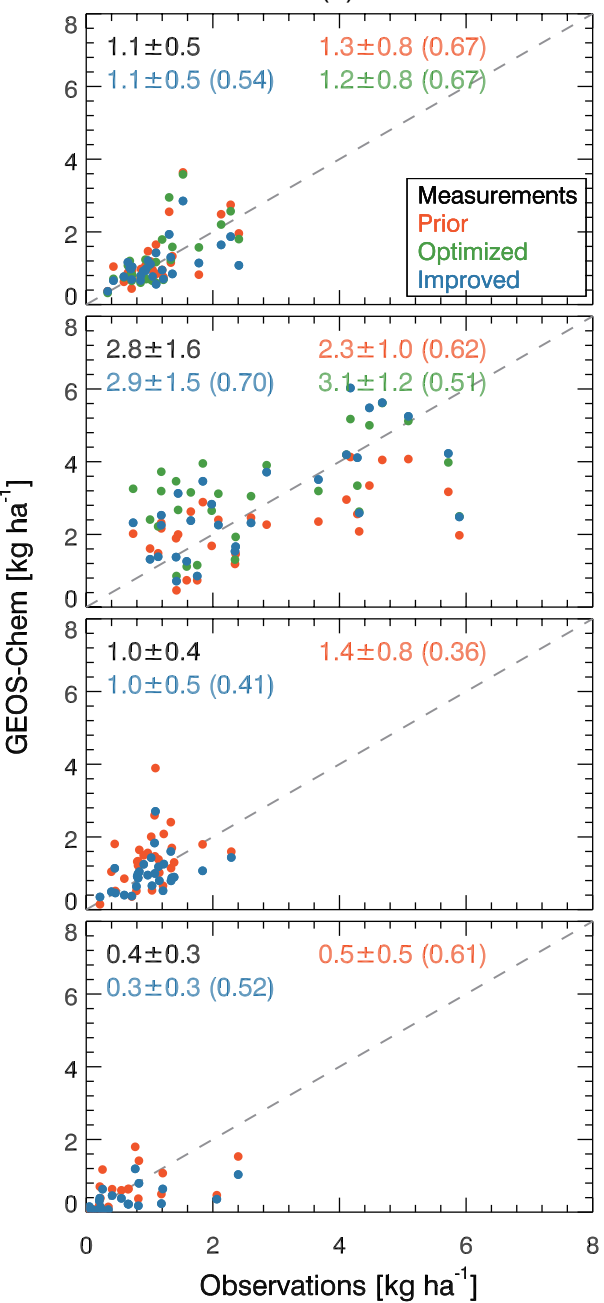

Figure 8. Comparison of simulated vs. measured seasonal mean $\mathrm{NH}_{4}^{+}$wet deposition fluxes over China. Spatial distributions (a) and scatterplots (b) are shown. Values inset are seasonal mean deposition fluxes and standard deviations for measurements (black), and model results with prior REAS v2 (orange), adjoint optimized (green; for spring and summer), and improved bottom-up (blue) $\mathrm{NH}_{3}$ emissions. The correlation coefficients (values in parentheses) and the $1: 1$ line (dashed line) are also shown.

\subsection{Improved emissions and evaluation with surface measurements}

Figure 7 presents our improved bottom-up estimates of $\mathrm{NH}_{3}$ emissions from fertilizer application, livestock waste, anthropogenic totals, and their seasonal variations. We adopt estimates of other $\mathrm{NH}_{3}$ sources (agricultural burning, chemical industry, transportation, and waste disposal) from Huang et al. (2012) for calculating the total anthropogenic $\mathrm{NH}_{3}$ emissions. Our bottom-up estimates show Chinese $\mathrm{NH}_{3}$ emissions of $5.05 \mathrm{Tg} \mathrm{a}^{-1}$ from fertilizer application and $5.31 \mathrm{Tg} \mathrm{a}^{-1}$ from livestock and reach $11.7 \mathrm{Tg} \mathrm{a}^{-1}$ with the addition of other anthropogenic sources. High $\mathrm{NH}_{3}$ emission rates occur over the North China Plain (over $80 \mathrm{~kg} \mathrm{ha}^{-1} \mathrm{a}^{-1}$ in parts of Hebei and Henan provinces) and the Sichuan Basin. Y. Zhang et al. (2010) also reported similar high $\mathrm{NH}_{3}$ emission (with highest value up to $198 \mathrm{kgha}^{-1} \mathrm{a}^{-1}$ ) in the North China Plain in the year 2004.

The spatial distribution and seasonal variations of our bottom-up $\mathrm{NH}_{3}$ emission inventory are also presented in Fig. 1 for comparison with previous estimates. The regional distribution of our bottom-up estimates is broadly similar to Huang et al. (2012) and REAS v2 but exhibits some important regional differences. The total anthropogenic emission estimate of $11.7 \mathrm{Tg} \mathrm{a}^{-1}$ is in the middle of previous bottomup estimates as summarized in Table 1; however, our $\mathrm{NH}_{3}$ emissions show much more distinct seasonal variations than previous estimates (e.g., Streets et al., 2003), with emissions a factor of 3 higher in summer than winter. As shown in Fig. 7, this strong seasonality is consistent with the adjoint optimized emission totals for March-October (50\% higher in summer than spring and fall), considering uncertainties 

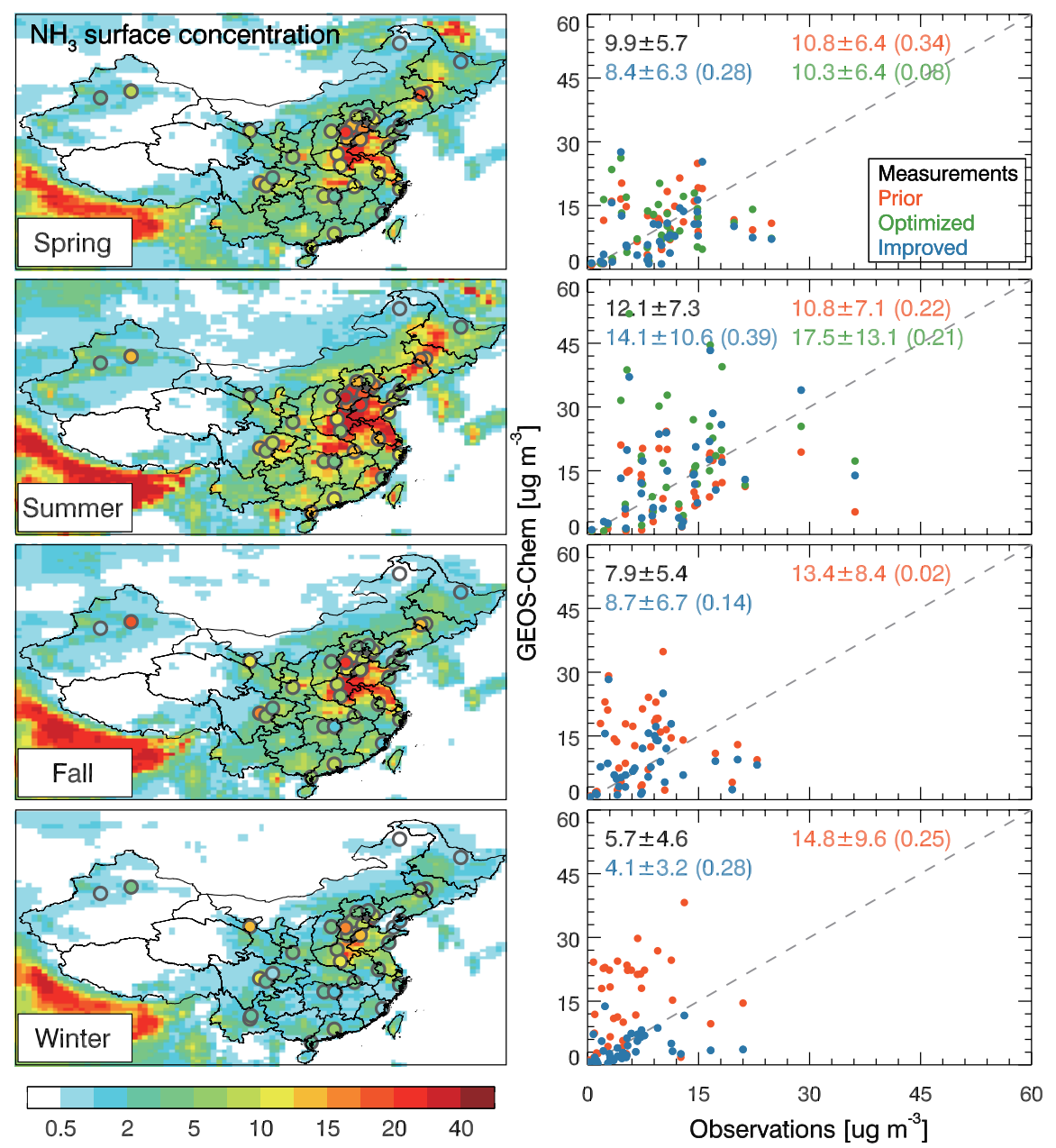

Figure 9. The same as Fig. 8, but for surface $\mathrm{NH}_{3}$ concentration.

in the inversion results and satellite retrievals. The improved bottom-up Chinese $\mathrm{NH}_{3}$ emissions are $\sim 15 \%$ higher than the top-down estimates in May and June and $\sim 20 \%$ lower in other months. This can also be seen from the comparison of simulated $\mathrm{NH}_{3}$ columns using the improved bottom-up inventory with the TES measurements (Fig. S1 in the Supplement).

For further and independent evaluation of these $\mathrm{NH}_{3}$ emissions, we use an ensemble of surface measurements of $\mathrm{NH}_{3}$ gas concentration and $\mathrm{NH}_{4}^{+}$wet deposition flux compiled by Zhao et al. (2017). The dataset includes monthly averages from a nationwide measurement network over China for 2011-2012 (Xu et al., 2015), 10 sites in the North China Plain monitored by the Chinese Academy of Sciences for 2008-2010 (Pan et al., 2012), and two sites in China from EANET (2015). It should be noted that these measurements are compared with simulated results for 2008 , inducing uncertainties from interannual variations. To test the influences from varying meteorology, we have conducted a model simulation over 2008-2012 with our improved bottom-up $\mathrm{NH}_{3}$ emissions and other $\mathrm{SO}_{2}$ and $\mathrm{NO}_{x}$ anthropogenic emissions fixed to the year 2008 conditions. Our results show small differences in simulated seasonal mean $\mathrm{NH}_{4}^{+}$wet deposition fluxes and $\mathrm{NH}_{3}$ gas concentrations between the 2008 and 5year averaged model results except for the wintertime surface $\mathrm{NH}_{3}$ concentrations for which the 2008 model results are $14 \%$ lower (Figs. 8 and 9 as discussed below vs. Fig. S2 in the Supplement).

We show in Fig. 8 comparisons of $\mathrm{NH}_{4}^{+}$wet deposition flux measurements with model results using improved bottom-up, prior (REAS v2), and optimized Chinese $\mathrm{NH}_{3}$ emissions. Measured $\mathrm{NH}_{4}^{+}$wet deposition fluxes indicate a strong peak in summer, with a national averaged monthly flux of $2.8 \pm 1.6 \mathrm{~kg} \mathrm{ha}^{-1} \mathrm{month}^{-1}$ and a minimum in winter $\left(0.4 \pm 0.3 \mathrm{~kg} \mathrm{ha}^{-1} \mathrm{month}^{-1}\right)$. Part of this seasonality is driven by heavier precipitation in summer as model results with the prior REAS v2 emissions also capture some of the summer vs. winter deposition flux differences. However, model results with the prior REAS v2 still show underestimates of the flux measurements in summer and overesti- 
mates in winter and spring, while the adjoint optimized $\mathrm{NH}_{3}$ emissions reduce the model biases (e.g., mean biases reduced from 18 to $9 \%$ in spring and from -18 to $11 \%$ in summer). We can see that model results with our improved bottom-up $\mathrm{NH}_{3}$ emissions reproduce the spatial and seasonal variations in measured $\mathrm{NH}_{4}^{+}$wet deposition fluxes well (correlation coefficients $r=0.41-0.70$ ).

Figure 9 shows comparisons for the surface $\mathrm{NH}_{3}$ gas concentration. Comparing model results with these surface concentration measurements requires addressing the inconsistency in the altitude they represent. The lowest model layer is centered at $70 \mathrm{~m}$ above surface, while all these Chinese surface sites used here measure at $3 \mathrm{~m}$ above surface. Zhang et al. (2012) previously quantified the vertical gradient of $\mathrm{HNO}_{3}$ concentrations in the lowest model layer based on the dry deposition resistance-in-series formulation and the Monin-Obukhov similarity theorem. Here we follow the same approach to estimate the $3 \mathrm{~m} / 70 \mathrm{~m}$ gradient of $\mathrm{NH}_{3}$ concentrations driven by net $\mathrm{NH}_{x}$ flux in each grid. Implied $\mathrm{NH}_{3}$ concentrations at $3 \mathrm{~m}$ are on average 20-30\% higher than those at $70 \mathrm{~m}$. As a result, model results with our improved bottom-up emissions show better agreement (with seasonal mean biases within $\pm 20 \%$ ) with surface $\mathrm{NH}_{3}$ concentration measurements than REAS v2 and optimized emissions. The relatively low correlation coefficients $(0.14$ 0.39 ) may reflect difficulties for the model to fully capture the heterogeneity in $\mathrm{NH}_{3}$ concentration due to its short lifetime, uncertainties gaseous $\mathrm{NH}_{3}$ and aerosol $\mathrm{NH}_{4}^{+}$partitioning, and also interannual variations in $\mathrm{NH}_{3}$ measurements. Furthermore, while land-atmosphere exchange of $\mathrm{NH}_{3}$ is bidirectional, the model here treats it as one-way emission and dry deposition processes. Zhu et al. (2015) previously implemented a bi-directional $\mathrm{NH}_{3}$ exchange algorithm in GEOSChem, and they found that it led to small changes in wet deposition fluxes but had large impacts on emission estimates and surface concentrations over eastern China. Future work is required to improve the bi-directional exchange processes in the model.

\section{Conclusions}

In summary, we have applied both bottom-up and top-down methods to better understand agricultural $\mathrm{NH}_{3}$ emissions in China. A review of recent bottom-up estimates of Chinese $\mathrm{NH}_{3}$ emissions shows substantial differences, not only in annual estimates of $\mathrm{NH}_{3}$ emissions from fertilizer application and livestock waste, but also in their spatial and seasonal variations. The large differences mainly reflect limited information on fertilizer application practices and uncertainties in emission factors of $\mathrm{NH}_{3}$ from agricultural activities.

We conduct top-down estimates of $\mathrm{NH}_{3}$ emissions in China by assimilating TES satellite observations of $\mathrm{NH}_{3}$ column concentration with the GEOS-Chem adjoint model for March-October 2008. The optimized Chinese $\mathrm{NH}_{3}$ emis- sions show a strong summer peak that is generally underestimated in current bottom-up emission estimates. Optimized monthly emissions in July are $1.90 \mathrm{Tg}(1.60-1.93 \mathrm{Tg}$ considering different configurations of error covariance), $\sim 50 \%$ higher than these in April (1.21 Tg) and October (1.29 Tg).

To interpret the top-down emission estimates, we revisit the bottom-up estimate of agricultural $\mathrm{NH}_{3}$ emissions, aiming to better estimate the fertilizer application practices and $\mathrm{NH}_{3}$ emission factors in China. We improve the emission inventory of Paulot et al. (2014) for $\mathrm{NH}_{3}$ from fertilizer application with more realistic estimates of fertilizer use magnitudes and growth schedules of main crop categories in China. Emission factors of $\mathrm{NH}_{3}$ from fertilizer application are calculated as a function of fertilizer type, application mode, soil property, and meteorological condition. Our validation of calculated values with an ensemble of published emission factor measurements shows a good agreement. For $\mathrm{NH}_{3}$ emissions from livestock waste, we follow the mass-flow approach of Huang et al. (2012) and further account for meteorological influences (air temperature and wind speed) on $\mathrm{NH}_{3}$ emission factors.

We find in our improved bottom-up inventory for the year 2008 that annual Chinese $\mathrm{NH}_{3}$ emissions are $5.05 \mathrm{Tg} \mathrm{a}^{-1}$ from fertilizer application and $5.31 \mathrm{Tg} \mathrm{a}^{-1}$ from livestock waste. Addition of other anthropogenic $\mathrm{NH}_{3}$ sources from Huang et al. (2012) $\left(1.3 \mathrm{Tg} \mathrm{a}^{-1}\right)$ suggests annual anthropogenic emissions of $11.7 \mathrm{Tg} \mathrm{a}^{-1}$. The improved bottom-up estimates of Chinese anthropogenic $\mathrm{NH}_{3}$ emissions now display a strong seasonality, with emissions in summer $\sim 50 \%$ higher than spring and a factor of 3 higher than winter, similar to the seasonality in the top-down emission estimates.

We further evaluate the improved bottom-up and top-down Chinese $\mathrm{NH}_{3}$ emissions using available surface measurements of $\mathrm{NH}_{3}$ gas concentration and $\mathrm{NH}_{4}^{+}$wet deposition flux. We find that model results with improved bottom-up emissions reproduce the spatial and seasonal variations in these surface measurements well, demonstrating improvements in $\mathrm{NH}_{3}$ emissions resulted from inclusion of detailed information on fertilizer application practices and seasonal variations of $\mathrm{NH}_{3}$ emission factors. We acknowledge that measurements used in the study (both surface and TES satellite measurements) are still sparse in spatial coverage. Future studies using satellite $\mathrm{NH}_{3}$ observations from AIRS, IASI, and CrIS that have better spatial data coverage will be valuable to constrain the spatial variability of $\mathrm{NH}_{3}$ emissions.

Data availability. The datasets including measurements and model simulations can be accessed from websites listed in the references or by contacting the corresponding author (Lin Zhang; zhanglg@pku.edu.cn). The Chinese agricultural $\mathrm{NH}_{3}$ emission inventory developed in this study can also be downloaded from the web page (http://www.phy.pku.edu.cn/ acaq/data/nh3_agr_emis. html). 


\section{The Supplement related to this article is available online at https://doi.org/10.5194/acp-18-339-2018-supplement.}

Competing interests. The authors declare that they have no conflict of interest.

Special issue statement. This article is part of the special issue "Regional transport and transformation of air pollution in eastern China”. It is not associated with a conference.

Acknowledgements. This work was funded by the National Key Research and Development Program of China (2017YFC0210102), China's National Basic Research Program (2014CB441303), and the National Natural Science Foundation of China (41205103, 41425007, and 41405144). Daven K. Henze recognizes support from NASA ACMAP (NNX17AF63G). We also acknowledge Mark W. Shephard, Karen E. Cady-Pereira, and the TES science team for making the TES $\mathrm{NH}_{3}$ data publicly available.

Edited by: Qiang Zhang

Reviewed by: Jeffrey Collett and two anonymous referees

\section{References}

Amos, H. M., Jacob, D. J., Holmes, C. D., Fisher, J. A., Wang, Q., Yantosca, R. M., Corbitt, E. S., Galarneau, E., Rutter, A. P., Gustin, M. S., Steffen, A., Schauer, J. J., Graydon, J. A., Louis, V. L. St., Talbot, R. W., Edgerton, E. S., Zhang, Y., and Sunderland, E. M.: Gas-particle partitioning of atmospheric $\mathrm{Hg}$ (II) and its effect on global mercury deposition, Atmos. Chem. Phys., 12, 591-603, https://doi.org/10.5194/acp-12-5912012, 2012.

Beer, R.: TES on the Aura mission: scientific objectives, measurements, and analysis overview, IEEE T. Geosci. Remote, 44, 1102-1105, 2006.

Beer, R., Shephard, M. W., Kulawik, S. S., Clough, S. A., Eldering, A., Bowman, K. W., Sander, S. P., Fisher, B. M., Payne, V. H., Luo, M., Osterman, G. B., and Worden, J. R.: First satellite observations of lower tropospheric ammonia and methanol, Geophys. Res. Lett., 35, L09801, https://doi.org/10.1029/2008g1033642, 2008.

Binkowski, F. S. and Roselle, S. J.: Models-3 Community Multiscale Air Quality (CMAQ) model aerosol component 1. Model description, J. Geophys. Res., 108, 4183, https://doi.org/10.1029/2001JD001409, 2003.

Bouwman, A. F., Lee, D. S., Asman, W. A. H., Dentener, F. J., VanderHoek, K. W., and Olivier, J. G. J.: A global high-resolution emission inventory for ammonia, Global Biogeochem. Cy., 11, 561-587, 1997.

Bouwman, A. F., Boumans, L. J. M., and Batjes, N. H.: Estimation of global $\mathrm{NH}_{3}$ volatilization loss from synthetic fertilizers and animal manure applied to arable lands and grasslands, Global Biogeochem. Cy., 16, 1024, https://doi.org/10.1029/2000GB001389, 2002.
Bowman, W. D., Cleveland, C. C., Halada, L., Hresko, J., and Baron, J. S.: Negative impact of nitrogen deposition on soil buffering capacity, Nat. Geosci., 1, 767-770, 2008.

Byrd, R. H., Lu, P. H., Nocedal, J., and Zhu, C. Y.: A limited memory algorithm for bound constrained optimization, SIAM J. Sci. Comput., 16, 1190-1208, 1995.

Cao, G. L., An, X. Q., Zhou, C. H., Ren, Y. Q., and Tu, J.: Emission inventory of air pollutants in China, China Environmental Science, 30, 900-906, 2010 (in Chinese with English abstract).

Chang, Y., Zou, Z., Deng, C., Huang, K., Collett, J. L., Lin, J., and Zhuang, G.: The importance of vehicle emissions as a source of atmospheric ammonia in the megacity of Shanghai, Atmos. Chem. Phys., 16, 3577-3594, https://doi.org/10.5194/acp-163577-2016, 2016.

Chen, D., Wang, Y., McElroy, M. B., He, K., Yantosca, R. M., and Le Sager, P.: Regional CO pollution and export in China simulated by the high-resolution nested-grid GEOS-Chem model, Atmos. Chem. Phys., 9, 3825-3839, https://doi.org/10.5194/acp-93825-2009, 2009.

Cheng, Y., Zheng, G., Wei, C., Mu, Q., Zheng, B., Wang, Z., Gao, M., Zhang, Q., He, K., Carmichael, G., Pöschl, U., and $\mathrm{Su}, \mathrm{H}$.: Reactive nitrogen chemistry in aerosol water as a source of sulfate during haze events in China, Sci. Adv., 2, e1601530, https://doi.org/10.1126/sciadv.1601530, 2016.

Clarisse, L., Clerbaux, C., Dentener, F., Hurtmans, D., and Coheur, P.-F.: Global ammonia distribution derived from infrared satellite observations, Nat. Geosci., 2, 479-483, 2009.

Dong, W. X., Xin, J., and Wang, S. X.: Temporal and spatial distribution of anthropogenic ammonia emissions in China: 19942006, Environ. Sci., 31, 1457-1463, 2010 (in Chinese with English abstract).

EANET: The Acid Deposition Monitoring Network in East Asia, available at: http://www.eanet.asia/index.html (last access: December 2015), 2015.

EarthStat: University of Minnesota's Institute on the Environment and the Ramankutty Lab at the University of British Columbia, Vancouver, available at: http://www.earthstat.org/ (last access: December 2015), 2015.

Erisman, J. W., Sutton, M. A., Galloway, J., Klimont, Z., and Winiwarter, W.: How a century of ammonia synthesis changed the world, Nat. Geosci., 1, 636-639, https://doi.org/10.1038/ngeo325, 2008.

FAOSTAT (Food and Agriculture Organization of the United Nations (FAO) Statistics Division): available at: http://www.fao.org/ faostat/ (last access: December 2015), 2015.

Fountoukis, C. and Nenes, A.: ISORROPIA II: a computationally efficient thermodynamic equilibrium model for $\mathrm{K}^{+}-$ $\mathrm{Ca}^{2+}-\mathrm{Mg}^{2+}-\mathrm{NH}_{4}^{+}-\mathrm{Na}^{+}-\mathrm{SO}_{4}^{2-}-\mathrm{NO}_{3}^{-}-\mathrm{Cl}^{-}-\mathrm{H}_{2} \mathrm{O}$ aerosols, Atmos. Chem. Phys., 7, 4639-4659, https://doi.org/10.5194/acp-74639-2007, 2007.

Fu, X., Wang, S. X., Ran, L. M., Pleim, J. E., Cooter, E., Bash, J. O., Benson, V., and Hao, J. M.: Estimating $\mathrm{NH}_{3}$ emissions from agricultural fertilizer application in China using the bi-directional CMAQ model coupled to an agro-ecosystem model, Atmos. Chem. Phys., 15, 6637-6649, https://doi.org/10.5194/acp-156637-2015, 2015.

Fu, X., Wang, S., Xing, J., Zhang, X., Wang, T., and Hao, J.: Increasing ammonia concentrations reduce the effectiveness of particle pollution control achieved via $\mathrm{SO}_{2}$ and $\mathrm{NO}_{x}$ emissions re- 
duction in East China, Environ. Sci. Technol. Lett., 4, 221-227, https://doi.org/10.1021/acs.estlett.7b00143, 2017.

Gilliland, A. B., Dennis, R. L., Roselle, S. J., and Pierce, T. E.: Seasonal $\mathrm{NH}_{3}$ emission estimates for the eastern United States based on ammonium wet concentrations and an inverse modeling method, J. Geophys. Res., 108, 4477, https://doi.org/10.1029/2002jd003063, 2003.

Gilliland, A. B., Wyat Appel, K., Pinder, R. W., and Dennis, R. L.: Seasonal $\mathrm{NH}_{3}$ emissions for the continental United States: inverse model estimation and evaluation, Atmos. Environ., 40, 4986-4998, 2006.

GLW (Gridded Livestock of the World): available at: http://www. fao.org/ag/againfo/resources/en/glw/home.html (last access: December 2015), 2015.

Gyldenkærne, S., Ambelas Skjøth, C., Hertel, O., and Ellermann, T.: A dynamical ammonia emission parameterization for use in air pollution models, J. Geophys. Res.-Atmos., 110, 12751287, https://doi.org/10.1029/2004jd005459, 2005.

Henze, D. K., Hakami, A., and Seinfeld, J. H.: Development of the adjoint of GEOS-Chem, Atmos. Chem. Phys., 7, 2413-2433, https://doi.org/10.5194/acp-7-2413-2007, 2007.

Henze, D. K., Seinfeld, J. H., and Shindell, D. T.: Inverse modeling and mapping US air quality influences of inorganic $\mathrm{PM}_{2.5}$ precursor emissions using the adjoint of GEOS-Chem, Atmos. Chem. Phys., 9, 5877-5903, https://doi.org/10.5194/acp-9-58772009, 2009.

Henze, D. K., Shindell, D. T., Akhtar, F., Spurr, R. J. D., Pinder, R. W., Loughlin, D., Kopacz, M., Sing, K., and Shim, C.: Spatially refined aerosol direct radiative forcing efficiencies, Environ. Sci. Technol., 46, 9511-9518, https://doi.org/10.1021/es301993s, 2012.

Huang, X., Song, Y., Li, M. M., Li, J. F., Huo, Q., Cai, X. H., Zhu, T., Hu, M., and Zhang, H. S.: A high-resolution ammonia emission inventory in China, Global Biogeochem. Cy., 26, GB1030, https://doi.org/10.1029/2011GB004161, 2012.

Huang, R. J., Zhang, Y., Bozzetti, C., Ho, K. F., Cao, J. J., Han, Y., Daellenbach, K. R., Slowik, J. G., Platt, S. M., Canonaco, F., Zotter, P., Wolf, R., Pieber, S. M., Bruns, E. A., Crippa, M., Ciarelli, G., Piazzalunga, A., Schwikowski, M., Abbaszade, G., Schnelle-Kreis, J., Zimmermann, R., An, Z., Szidat, S., Baltensperger, U., El Haddad, I., and Prevot, A. S.: High secondary aerosol contribution to particulate pollution during haze events in China, Nature, 514, 218-222, https://doi.org/10.1038/nature13774, 2014.

IFA (International Fertilizer Industry Association): Assessment of Fertilizer Use by Crop at the Global Level, Paris, France, 2013.

ISRIC WSI (ISRIC-World Soil Information): available at: http: //www.isric.org (last access: December 2015), 2015.

Kang, Y., Liu, M., Song, Y., Huang, X., Yao, H., Cai, X., Zhang, H., Kang, L., Liu, X., Yan, X., He, H., Zhang, Q., Shao, M., and Zhu, T.: High-resolution ammonia emissions inventories in China from 1980 to 2012, Atmos. Chem. Phys., 16, 2043-2058, https://doi.org/10.5194/acp-16-2043-2016, 2016.

Kharol, S. K., Martin, R. V., Philip, S., Vogel, S., Henze, D. K., Chen, D., Wang, Y., Zhang, Q., and Heald, C. L.: Persistent sensitivity of Asian aerosol to emissions of nitrogen oxides, Geophys. Res. Lett., 40, 1-6, https://doi.org/10.1002/grl.50234, 2013.

Kurokawa, J., Ohara, T., Morikawa, T., Hanayama, S., JanssensMaenhout, G., Fukui, T., Kawashima, K., and Akimoto, H.:
Emissions of air pollutants and greenhouse gases over Asian regions during 2000-2008: Regional Emission inventory in ASia (REAS) version 2, Atmos. Chem. Phys., 13, 11019-11058, https://doi.org/10.5194/acp-13-11019-2013, 2013.

Kopacz, M., Jacob, D. J., Henze, D. K., Heald, C. L., Streets, D. G., and Zhang, Q.: Comparison of adjoint and analytical Bayesian inversion methods for constraining Asian sources of carbon monoxide using satellite (MOPITT) measurements of CO columns, J. Geophys. Res.-Atmos., 114, D04305, https://doi.org/10.1029/2007JD009264, 2009.

Lelieveld, J., Evans, J. S., Fnais, M., Giannadaki, D., and Pozzer, A.: The contribution of outdoor air pollution sources to premature mortality on a global scale, Nature, 525, 367-371, https://doi.org/10.1038/nature15371, 2015.

Li, K., Liao, H., Zhu, J., and Moch, J.: Implications of RCP emissions on future $\mathrm{PM}_{2.5}$ air quality and direct radiative forcing over China, J. Geophys. Res.-Atmos., 121, 12985-13008, https://doi.org/10.1002/2016JD025623, 2016.

Li, X. Y. and Li, H. P.: Emission and distribution of $\mathrm{NH}_{3}$ and $\mathrm{NO}_{x}$ in China, China Environmental Science, 32, 37-42, 2012 (in Chinese with English abstract).

Liao, J.: Fertilizer Application and Analysis, Shanghai Science and Technology Press, Shanghai, 1993 (in Chinese).

Liu, H. Y., Jacob, D. J., Bey, I., and Yantosca, R. M.: Constraints from $\mathrm{Pb}-210$ and $\mathrm{Be}-7$ on wet deposition and transport in a global three-dimensional chemical tracer model driven by assimilated meteorological fields, J. Geophys. Res., 106, 1210912128, 2001.

Mao, J., Jacob, D. J., Evans, M. J., Olson, J. R., Ren, X., Brune, W. H., Clair, J. M. St., Crounse, J. D., Spencer, K. M., Beaver, M. R., Wennberg, P. O., Cubison, M. J., Jimenez, J. L., Fried, A., Weibring, P., Walega, J. G., Hall, S. R., Weinheimer, A. J., Cohen, R. C., Chen, G., Crawford, J. H., McNaughton, C., Clarke, A. D., Jaeglé, L., Fisher, J. A., Yantosca, R. M., Le Sager, P., and Carouge, C.: Chemistry of hydrogen oxide radicals $\left(\mathrm{HO}_{x}\right)$ in the Arctic troposphere in spring, Atmos. Chem. Phys., 10, 5823-5838, https://doi.org/10.5194/acp10-5823-2010, 2010.

Mao, Y. H., Li, Q. B., Henze, D. K., Jiang, Z., Jones, D. B. A., Kopacz, M., He, C., Qi, L., Gao, M., Hao, W.-M., and Liou, K.-N.: Estimates of black carbon emissions in the western United States using the GEOS-Chem adjoint model, Atmos. Chem. Phys., 15, 7685-7702, https://doi.org/10.5194/acp15-7685-2015, 2015.

Martin, S. T., Hung, H.-M., Park, R. J., Jacob, D. J., Spurr, R. J. D., Chance, K. V., and Chin, M.: Effects of the physical state of tropospheric ammonium-sulfate-nitrate particles on global aerosol direct radiative forcing, Atmos. Chem. Phys., 4, 183214, https://doi.org/10.5194/acp-4-183-2004, 2004.

Monfreda, C., Ramankutty, N., and Foley, J. A.: Farming the planet: 2. Geographic distribution of crop areas, yields, physiological types, and net primary production in the year 2000, Global Biogeochem. Cy., 22, GB1022, https://doi.org/10.1029/2007GB002947, 2008.

NBSC (National Bureau of Statistics of China): available at http: //data.stats.gov.cn/ (last access: December 2015), 2015.

Olivier, J. G. J. and Berdowski, J. J. M.: Global emissions sources and sinks, in: The Climate System, edited by: Berdowski, J., Guicherit, R., and Heij, B. J., A. A. Balkema Publishers/Swets 
and Zeitlinger Publishers, Lisse, the Netherlands, 33-78, ISBN: 9058092550, 2001.

Pan, Y., Tian, S., Liu, D., Fang, Y., Zhu, X., Zhang, Q., Zheng, B., Michalski, G., and Wang, Y.: Fossil fuel combustion-related emissions dominate atmospheric ammonia sources during severe haze episodes: evidence from ${ }^{15} \mathrm{~N}$-stable isotope in size-resolved aerosol ammonium, Environ. Sci. Technol, 50, 8049-8056, 2016.

Pan, Y. P., Wang, Y. S., Tang, G. Q., and Wu, D.: Wet and dry deposition of atmospheric nitrogen at ten sites in Northern China, Atmos. Chem. Phys., 12, 6515-6535, https://doi.org/10.5194/acp12-6515-2012, 2012.

Park, R. J., Jacob, D. J., Field, B. D., Yantosca, R. M., and Chin, M.: Natural and transboundary pollution influences on sulfate-nitrate-ammonium aerosols in the United States: implications for policy, J. Geophys. Res.-Atmos., 109, D15204, https://doi.org/10.1029/2003jd004473, 2004.

Paulot, F., Jacob, D. J., Pinder, R. W., Bash, J. O., Travis, K., and Henze, D. K.: Ammonia emissions in the United States, European Union, and China derived by highresolution inversion of ammonium wet deposition data: interpretation with a new agricultural emissions inventory (MASAGE_NH3), J. Geophys. Res.-Atmos., 119, 4343-4364, https://doi.org/10.1002/2013JD021130, 2014.

Paulot, F., Fan, S.-M., and Horowitz, L. W.: Contrasting seasonal responses of sulfate aerosols to declining $\mathrm{SO}_{2}$ emissions in the eastern US: implications for the efficacy of $\mathrm{SO}_{2}$ emission controls, Geophys. Res. Lett., 43, 455-464, https://doi.org/10.1002/2016GL070695, 2016.

Pinder, R. W., Adams, P. J., Pandis, S. N., and Gilliland, A. B.: Temporally resolved ammonia emission inventories: current estimates, evaluation tools, and measurement needs, J. Geophys. Res.-Atmos., 111, 1984-2012, 2006.

Qu, Z., Henze, D. K., Capps, S. L., Wang, Y., Xu, X., and Wang, J.: Monthly top-down $\mathrm{NO}_{x}$ emissions for China (2005-2012): a hybrid inversion method and trend analysis, J. Geophys. Res., 122, 4600-4625, https://doi.org/10.1002/2016JD025852, 2017.

Sacks, W. J., Deryng, D., Foley, J. A., and Ramankutty, N.: Crop planting dates: an analysis of global patterns, Global Ecol. Biogeogr., 19, 607-620, 2010.

SAGE (Sustainability and the Global Environment): University of Wisconsin, available at: https://nelson.wisc.edu/sage/ data-and-models/atlas/maps.php (last access: December 2015), 2015.

Shephard, M. W. and Cady-Pereira, K. E.: Cross-track Infrared Sounder (CrIS) satellite observations of tropospheric ammonia, Atmos. Meas. Tech., 8, 1323-1336, https://doi.org/10.5194/amt8-1323-2015, 2015.

Shephard, M. W., Cady-Pereira, K. E., Luo, M., Henze, D. K., Pinder, R. W., Walker, J. T., Rinsland, C. P., Bash, J. O., Zhu, L., Payne, V. H., and Clarisse, L.: TES ammonia retrieval strategy and global observations of the spatial and seasonal variability of ammonia, Atmos. Chem. Phys., 11, 10743-10763, https://doi.org/10.5194/acp-11-10743-2011, 2011.

Søgaard, H. T., Sommer, S. G., Hutchings, N. J., Huijsmans, J. F. M., Bussink, D. W., and Nicholson, F.: Ammonia volatilization from field-applied animal slurry the ALFAM model, Atmos. Environ., 36, 3309-3319, https://doi.org/10.1016/S1352-2310(02)00300-X, 2002.
Stevens, C. J., Dise, N. B., Mountford, J. O., and Gowing, D. J.: Impact of nitrogen deposition on the species richness of grasslands, Science, 303, 1876-1879, 2004.

Streets, D. G., Bond, T. C., Carmichael, G. R., Fernandes, S. D., Fu, Q., He, D., Klimont, Z., Nelson, S. M., Tsai, N. Y., Wang, M. Q., Woo, J. H., and Yarber, K. F.: An inventory of gaseous and primary aerosol emissions in Asia in the year 2000, J. Geophys. Res.-Atmos., 108, 8809, https://doi.org/10.1029/2002JD003093, 2003.

Sun, K., Tao, L., Miller, D. J., Pan, D., Golston, L. M., Zondlo, M. A., Griffin, R. J., Wallace, H. W., Leong, Y. J., Yang, M. M., Zhang, Y., Mauzerall, D. L., and Zhu, T.: Vehicle emissions as an important urban ammonia source in the United States and China, Environ. Sci. Technol., 51, 2472-2481, https://doi.org/10.1021/acs.est.6b02805, 2017.

Teng, X., Hu, Q., Zhang, L., Qi, J., Shi, J., Xie, H., Gao, H., and Yao, X.: Identification of major sources of atmospheric $\mathrm{NH}_{3}$ in an urban environment in northern China during wintertime, Environ. Sci. Technol., 51, 6839-6848, https://doi.org/10.1021/acs.est.7b00328, 2017.

Van Damme, M., Clarisse, L., Dammers, E., Liu, X., Nowak, J. B., Clerbaux, C., Flechard, C. R., Galy-Lacaux, C., Xu, W., Neuman, J. A., Tang, Y. S., Sutton, M. A., Erisman, J. W., and Coheur, P. F.: Towards validation of ammonia $\left(\mathrm{NH}_{3}\right)$ measurements from the IASI satellite, Atmos. Meas. Tech., 8, 15751591, https://doi.org/10.5194/amt-8-1575-2015, 2015.

van Donkelaar, A., Martin, R. V., Leaitch, W. R., Macdonald, A. M., Walker, T. W., Streets, D. G., Zhang, Q., Dunlea, E. J., Jimenez, J. L., Dibb, J. E., Huey, L. G., Weber, R., and Andreae, M. O.: Analysis of aircraft and satellite measurements from the Intercontinental Chemical Transport Experiment (INTEX-B) to quantify long-range transport of East Asian sulfur to Canada, Atmos. Chem. Phys., 8, 2999-3014, https://doi.org/10.5194/acp-8-2999-2008, 2008.

Wang, G., Zhang, R., Gomez, M. E., Yang, L., Levy Zamora, M., Hu, M., Lin, Y., Peng, J., Guo, S., Meng, J., Li, J., Cheng, C., Hu, T., Ren, Y., Wang, Y., Gao, J., Cao, J., An, Z., Zhou, W., Li, G., Wang, J., Tian, P., Marrero-Ortiz, W., Secrest, J., Du, Z., Zheng, J., Shang, D., Zeng, L., Shao, M., Wang, W., Huang, Y., Wang, Y., Zhu, Y., Li, Y., Hu, J., Pan, B., Cai, L., Cheng, Y., Ji, Y., Zhang, F., Rosenfeld, D., Liss, P. S., Duce, R. A., Kolb, C. E., and Molina, M. J.: Persistent sulfate formation from London Fog to Chinese haze, P. Natl. Acad. Sci. USA, 113, 13630-13635, https://doi.org/10.1073/pnas.1616540113, 2016.

Wang, J., Hoffmann, A. A., Park, R. J., Jacob, D. J., and Martin, S. T.: Global distribution of solid and aqueous sulfate aerosols: effect of the hysteresis of particle phase transitions, J. Geophys. Res., 113, D11206, https://doi.org/10.1029/2007jd009367, 2008.

Wang, Q., Jacob, D. J., Fisher, J. A., Mao, J., Leibensperger, E. M., Carouge, C. C., Le Sager, P., Kondo, Y., Jimenez, J. L., Cubison, M. J., and Doherty, S. J.: Sources of carbonaceous aerosols and deposited black carbon in the Arctic in winter-spring: implications for radiative forcing, Atmos. Chem. Phys., 11, 1245312473, https://doi.org/10.5194/acp-11-12453-2011, 2011.

Wang, S. W., Liao, Q. J. H., Hu, Y. T., and Yan, X. Y.: A preliminary inventory of $\mathrm{NH}_{3}-\mathrm{N}$ emission and its temporal and spatial distribution of China, Journal of Agro-Environment Science, 28, 619-626, 2009 (in Chinese with English abstract). 
Wang, Y., Zhang, Q. Q., He, K., Zhang, Q., and Chai, L.: Sulfate-nitrate-ammonium aerosols over China: response to 2000-2015 emission changes of sulfur dioxide, nitrogen oxides, and ammonia, Atmos. Chem. Phys., 13, 2635-2652, https://doi.org/10.5194/acp-13-2635-2013, 2013.

Wang, Y. X., McElroy, M. B., Jacob, D. J., and Yantosca, R. M.: A nested grid formulation for chemical transport over Asia: applications to CO, J. Geophys. Res., 109, D22307, https://doi.org/10.1029/2004jd005237, 2004.

Warner, J. X., Wei, Z., Strow, L. L., Dickerson, R. R., and Nowak, J. B.: The global tropospheric ammonia distribution as seen in the 13-year AIRS measurement record, Atmos. Chem. Phys., 16, 5467-5479, https://doi.org/10.5194/acp-165467-2016, 2016.

Warner, J. X., Dickerson, R. R., Wei, Z., Strow, L. L., Wang, Y., and Liang, Q.: Increased atmospheric ammonia over the world's major agricultural areas detected from space, Geophys. Res. Lett., 44, 2875-2884, https://doi.org/10.1002/2016GL072305, 2017.

Wesely, M. L.: Parameterization of surface resistances to gaseous dry deposition in regional-scale numerical-models, Atmos. Environ., 23, 1293-1304, 1989

Xu, P., Liao, Y. J., Lin, Y. H., Zhao, C. X., Yan, C. H., Cao, M. N., Wang, G. S., and Luan, S. J.: High-resolution inventory of ammonia emissions from agricultural fertilizer in China from 1978 to 2008, Atmos. Chem. Phys., 16, 1207-1218, https://doi.org/10.5194/acp-16-1207-2016, 2016.

Xu, W., Luo, X. S., Pan, Y. P., Zhang, L., Tang, A. H., Shen, J. L., Zhang, Y., Li, K. H., Wu, Q. H., Yang, D. W., Zhang, Y. Y., Xue, J., Li, W. Q., Li, Q. Q., Tang, L., Lu, S. H., Liang, T., Tong, Y. A., Liu, P., Zhang, Q., Xiong, Z. Q., Shi, X. J., Wu, L. H., Shi, W. Q., Tian, K., Zhong, X. H., Shi, K., Tang, Q. Y., Zhang, L. J., Huang, J. L., He, C. E., Kuang, F. H., Zhu, B., Liu, H., Jin, X., Xin, Y. J., Shi, X. K., Du, E. Z., Dore, A. J., Tang, S., Collett Jr., J. L., Goulding, K., Sun, Y. X., Ren, J., Zhang, F. S., and Liu, X. J.: Quantifying atmospheric nitrogen deposition through a nationwide monitoring network across China, Atmos. Chem. Phys., 15, 12345-12360, https://doi.org/10.5194/acp-15-12345-2015, 2015.

Yan, X., Akimoto, H., and Ohara, T.: Estimation of nitrous oxide, nitric oxide and ammonia emissions from croplands in East, Southeast and South Asia, Glob. Change Biol., 9, 1080-1096, https://doi.org/10.1046/j.1365-2486.2003.00649.x, 2003.

Yang, F., Tan, J., Zhao, Q., Du, Z., He, K., Ma, Y., Duan, F., Chen, G., and Zhao, Q.: Characteristics of $\mathrm{PM}_{2.5}$ speciation in representative megacities and across China, Atmos. Chem. Phys., 11, 5207-5219, https://doi.org/10.5194/acp-115207-2011, 2011.

Zhang, L., Gong, S., Padro, J., and Barrie, L.: A size-segregated particle dry deposition scheme for an atmospheric aerosol module. Atmos. Environ., 35, 549-560, 2001.

Zhang, L., Jacob, D. J., Liu, X., Logan, J. A., Chance, K., Eldering, A., and Bojkov, B. R.: Intercomparison methods for satellite measurements of atmospheric composition: application to tropospheric ozone from TES and OMI, Atmos. Chem. Phys., 10, 4725-4739, https://doi.org/10.5194/acp-10-4725-2010, 2010.

Zhang, L., Jacob, D. J., Knipping, E. M., Kumar, N., Munger, J. W., Carouge, C. C., van Donkelaar, A., Wang, Y. X., and Chen, D.: Nitrogen deposition to the United States: distribution, sources, and processes, Atmos. Chem. Phys., 12, 4539-4554, https://doi.org/10.5194/acp-12-4539-2012, 2012.

Zhang, L., Liu, L., Zhao, Y., Gong, S., Zhang, X., Henze, D. K., Capps, S. L., Fu, T.-M., Zhang, Q., and Wang, Y.: Source attribution of particulate matter pollution over North China with the adjoint method, Environ. Res. Lett., 10, 084011, https://doi.org/10.1088/1748-9326/10/8/084011, 2015.

Zhang, L., Shao, J., Lu, X., Zhao, Y., Hu, Y., Henze, D. K., Liao, H., Gong, S., and Zhang, Q.: Sources and processes affecting fine particulate matter pollution over North China: an adjoint analysis of the Beijing APEC period, Environ. Sci. Technol., 50, 87318740, https://doi.org/10.1021/acs.est.6b03010, 2016.

Zhang, Q., Streets, D. G., Carmichael, G. R., He, K. B., Huo, H., Kannari, A., Klimont, Z., Park, I. S., Reddy, S., Fu, J. S., Chen, D., Duan, L., Lei, Y., Wang, L. T., and Yao, Z. L.: Asian emissions in 2006 for the NASA INTEX-B mission, Atmos. Chem. Phys., 9, 5131-5153, https://doi.org/10.5194/acp-9-51312009, 2009.

Zhang, W. F. and Zhang, F. S.: Report on the Development of Fertilizer in China, China Agriculture University Press, China, 2012 (in Chinese).

Zhang, Y., Dore, A. J., Ma, L., Liu, X. J., Ma, W. Q., Cape, J. N., and Zhang, F. S.: Agricultural ammonia emissions inventory and spatial distribution in the North China Plain, Environ. Pollut., 158, 490-501, https://doi.org/10.1016/j.envpol.2009.08.033, 2010.

Zhang, Y. S., Luan, S. J., Chen, L. L., and Shao, M.: Estimating the volatilization of ammonia from synthetic nitrogenous fertilizers used in China, J. Environ. Manage., 92, 480-493, https://doi.org/10.1016/j.jenvman.2010.09.018, 2011.

Zhao, B., Wang, S. X., Wang, J. D., Fu, J. S., Liu, T. H., $\mathrm{Xu}, \mathrm{J} . \mathrm{Y} ., \mathrm{Fu}, \mathrm{X}$. , and Hao, J. M.: Impact of national $\mathrm{NO}_{x}$ and $\mathrm{SO}_{2}$ control policies on particulate matter pollution in China, Atmos. Environ., 77, 453-463, https://doi.org/10.1016/j.atmosenv.2013.05.012, 2013.

Zhao, Y., Zhang, L., Pan, Y., Wang, Y., Paulot, F., and Henze, D. K.: Atmospheric nitrogen deposition to the northwestern Pacific: seasonal variation and source attribution, Atmos. Chem. Phys., 15, 10905-10924, https://doi.org/10.5194/acp-15-10905-2015, 2015.

Zhao, Y., Zhang, L., Chen, Y., Liu, X., Xu, W., Pan, Y., and Duan, L.: Atmospheric nitrogen deposition to China: a model analysis on nitrogen budget and critical load exceedance, Atmos. Environ., 153, 32-40, 2017.

Zhu, L., Henze, D. K., Cady-Pereira, K. E., Shephard, M. W., Luo, M., Pinder, R. W., Bash, J. O., and Jeong, G. R.: Constraining U.S. ammonia emissions using TES remote sensing observations and the GEOS-Chem adjoint model, J. Geophys. Res.Atmos., 118, 3355-3368, 2013.

Zhu, L., Henze, D., Bash, J., Jeong, G.-R., Cady-Pereira, K., Shephard, M., Luo, M., Paulot, F., and Capps, S.: Global evaluation of ammonia bidirectional exchange and livestock diurnal variation schemes, Atmos. Chem. Phys., 15, 12823-12843, https://doi.org/10.5194/acp-15-12823-2015, 2015. 